\title{
Active fault characterization and seismotectonic zoning of the Hispaniola island
}

\author{
Monique Terrier-Sedan (D) Didier Bertil
}

Received: 22 June 2020 / Accepted: 18 January 2021 / Published online: 18 February 2021

(C) The Author(s) 2021

\begin{abstract}
Designing a seismic source model based on the most complete description of potentially active faults and on the kinematics of their latest movements is an essential requirement in seismic hazard studies, at regional and local scales. A study to characterize active faults in the Hispaniola island (today's Haiti and Dominican Republic) has been conducted in the framework of the probabilistic seismic hazard assessment for Santo Domingo (capital of the Dominican Republic). In this work, we present a seismotectonic map of Hispaniola and its surroundings, based on a compilation and synthesis of geological, geophysical, geodetic and seismological data. Based on these data, distinct seismic zone sources are proposed and classified as either intercrustal domains, major active faults or subduction zones. Each seismic source is described according to several parameters, including its mechanism and current rate of deformation, the associated seismicity and its estimated maximal magnitude. These results constitute an essential database for a homogeneous evaluation of the seismic hazards of Hispaniola.
\end{abstract}

Article highlights Between the Caribbean and North American plates, the island of Hispaniola is in an active seismic zone. Historical records indicate at least 13 earthquakes of magnitude over 7.0, of which 8.0 took place in the last 300 years. A map of active faults and seismotectonic zoning are proposed. Despite the uncertainties, this result is essential to provide an updated assessment of seismic hazards on the island.

M. Terrier-Sedan $(\square) \cdot$ D. Bertil

Risk and Prevention Division, BRGM, 3, avenue

Claude-Guillemin, BP 36009, 45060 Orléans Cedex 2, France

e-mail: m.terrier@brgm.fr
Keywords Active fault - Seismotectonic zonation . Seismic hazard $\cdot$ Hispaniola $\cdot$ Caribbean arc

\section{Introduction}

The island of Hispaniola, which includes Haiti and the Dominican Republic, is located on the northeastern limit of the North American and Caribbean plates (Fig. 1). It is a strongly active seismic region of the Greater Antilles arc on the Caribbean plate. The $2010 \mathrm{Mw} 7.0$ earthquake which devastated the whole Leogane-Port-auPrince area (Calais et al. 2010; Rathje et al. 2011; Symithe et al. 2013; Douilly et al. 2013, 2015), is part of a long list of destructive earthquakes that have struck Hispaniola during the last centuries (ten Brink et al. 2011; Flores et al. 2011; Bakun et al. 2012) This earthquake was a dramatic wakeup call that brought attention to a long underestimated hazard to the Hispaniola island. Since then, the governments of the two countries composing the island have been making efforts to evaluate the seismic hazard, so that appropriate mitigation plans can be put in place. The present work has been conducted in the framework of a project to assess the seismic hazard and vulnerability of the Gran Santo Domingo area in the Dominican Republic (Bertil et al. 2015). Additional seismic micro-zoning studies conducted in Haiti since 2010 (Bertil et al. 2013) were also consulted.

The current methodology for assessing probabilistic seismic hazard at any scale begins with the identification of seismic sources within or near the area under study, their geometry, and statistical models describing their 
activity. Modelling seismic sources is one of the fundamental aspects of reliable seismic hazard assessment. Even though Hispaniola belongs to a region of important seismic activity, modelling seismic sources is a challenging task that needs to be conducted with care, given the insufficient level of information available on seismic sources and observed seismicity, and their highly variable degree of confidence. In this paper, we propose a source characterization and seismotectonic zoning for Hispaniola, based on the most up-to-date knowledge.

\section{Geological and seismic context}

With the islands of Puerto Rico and Jamaica, Hispaniola belongs to the Greater Antilles arc, located at the junction of the North American and Caribbean plates. Cuba, geographically, also belongs to the Greater Antilles and originates from the Caribbean lithosphere. It is after the middle Eocene that the opening of the Cayman trough left the Yucatan basin and Cuba as part of the North American plate (Pindell and Kennan 2009; Stanek et al. 2009). Today, the Caribbean plate is bounded to the east and west by subduction zones (of the Cocos and American plates under the Caribbean plate, respectively), and to the north by transform transtensional fault of Motagua fault and Cayman trough or to the south by transform transpressional Oca-El Pilar fault system (Molnar and Sykes 1969), Fig. 1.

GPS data and geological reconstruction indicate that the Caribbean plate is in relative motion of 18 to $20 \mathrm{~mm} /$ year, along a mean direction of $70^{\circ} \mathrm{N}$, towards the North American plate (Calais et al. 2002; DeMets and Wiggins-Grandison 2007; Manaker et al. 2008; DeMets et al. 2010; Hayes et al. 2010; Symithe et al. 2015). Its northern limit with the North American plate is globally oriented east-west. At the level of the island of Hispaniola, the oblique collision of the two plates induces partitioned deformations, with the development of tectonic structures with a main thrust or strike-slip movement (Dolan et al. 1998; Mann et al. 1995, 2002).

Hispaniola is at the juxtaposition of different structural blocks characterized by distinct geodynamic evolutions and separated by large-scale shear zones (Mann et al. 1991, 2002), Fig. 2. Among the shear zones are to the north, the SeptentrionalOriente fault zone and to the south, the Enriquillo-
Plantain-Garden fault zone. The North Hispaniola fault marks the zone of subduction of the North American plate under the Caribbean plate. The thrust faults of the Cordillera Central and the Muertos fault accommodate a part of the compressive deformation in the Caribbean lithosphere (Byrne et al. 1985; BijuDuval et al. 1982; Dillon et al. 1992; Mann et al. 1984, 1995).

For the development of a seismic source model, a unified catalogue of earthquakes was established by collecting and analysing historical data (Scherer and Baltenweck 1913; Iniguez 1985; Chuy and Alvarez 1988; Grases 1990; SISFRANCE-Antilles 2009; Flores et al. 2011; McCann et al. 2011; Bakun et al. 2012; ten Brink et al. 2011; Dolan and Bowman 2004; etc.) and experimental data (Gutenberg and Richter 1954; Sykes and Ewing 1965; Russo and Villaseñor 1995; Alvarez et al. 1999; Tanner and Shepherd 1997; ISC 2014; RSPR-Puerto Rico, USGC-NEIC catalogues). We reviewed the studies for data quality, duplication, and foreshocks or aftershocks, and then homogenized the magnitudes using the moment magnitude scale $(\mathrm{Mw})$. To best clarify the focal characteristics of historical earthquakes, we sought to find the most contemporary sources describing the seismic events. Although there are uncertainties regarding the magnitude and location, the catalogue of seismicity is considered complete from 1945 onwards for magnitudes above 5.5 and complete from 1964 onwards for magnitudes above 5.0. The oldest known earthquake occurred in 1562. More than 25 epicentres of earthquakes of magnitude at least 6.5 $\mathrm{Mw}$ are located in Hispaniola or the immediate surroundings, including the earthquakes of magnitude above 7.5 , of $1562,1615,1691,1751$, 1770, 1842 and 1946, Fig. 2 (see catalogue in the electronic supplemental table).

The seismicity in the areas surrounding Cuba and Hispaniola clearly indicates the capacity of the border between the Caribbean and North American plates to generate strong events. The instrumental seismicity indicates a spatial distribution, Fig. 3, which is (i) superficial and confined along the faults to the west of Hispaniola and (ii) superficial, deep and distributed to the east of Hispaniola. The deep seismicity marks the subduction plane of the North American plate under the Caribbean plate, which disappears to the west of longitude $71^{\circ} \mathrm{W}$, Fig. 2. 


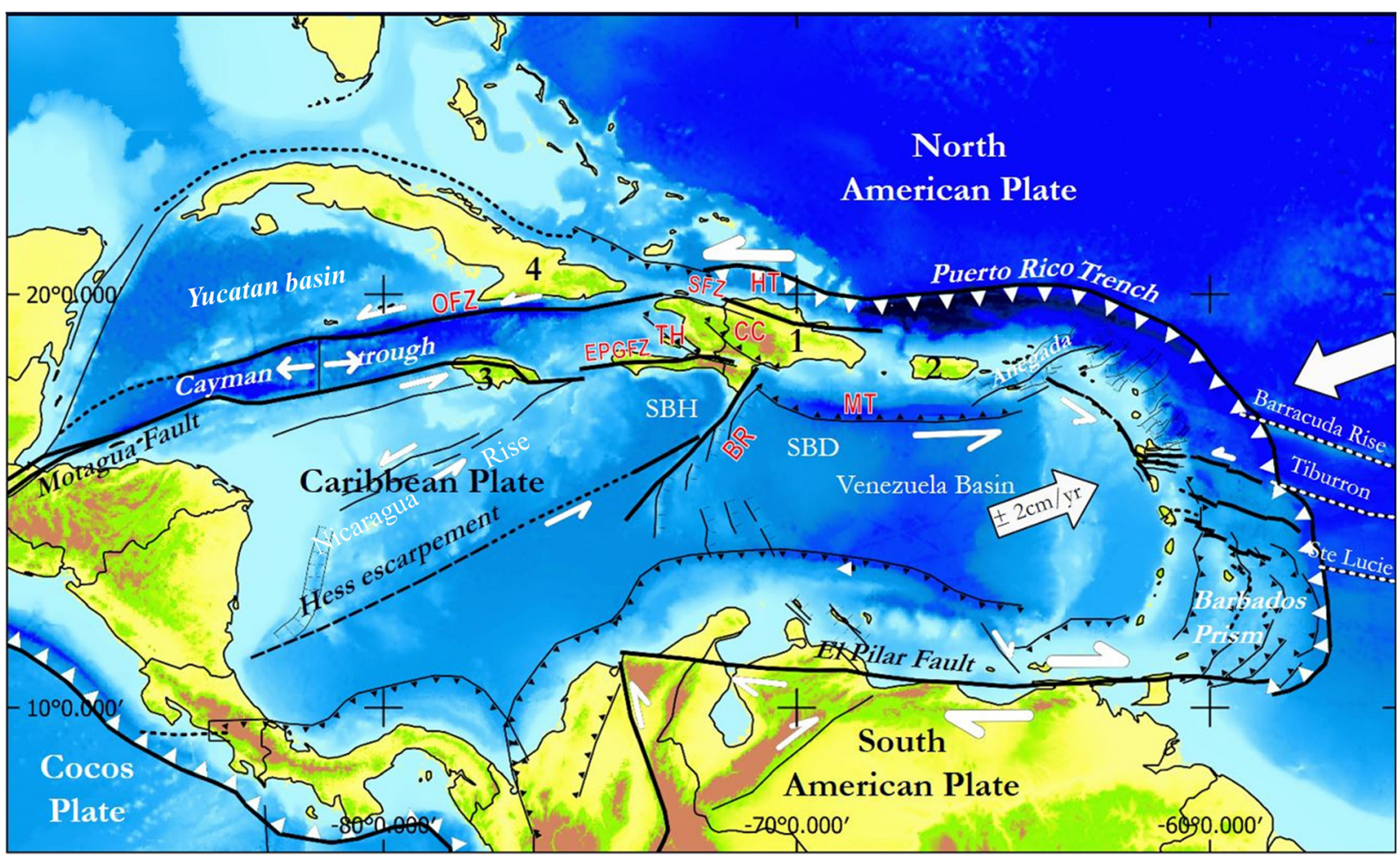

Fig. 1 Location of Hispaniola on the present-day tectonic map of the Caribbean region modified from Pindell and Kennan 2009). BRFZ: Beata ridge fault zone; CC: Central Cordillera; EPGFZ: Enriquillo-Plantain-Garden fault zone; HT: Hispaniola trench;

All the plate kinematic models generated from geodetic GPS measurements (including Manaker et al. 2008; Benford et al. 2012; Calais et al. 2016) indicate a subduction speed of the North American plate strongly decreasing along the east to west direction, between $16 \mathrm{~mm} /$ year to the north of Puerto Rico and $3.0 \mathrm{~mm} / \mathrm{year}$ to the north of Haiti. The Septentrional fault zone displays a strike-slip movement, with speeds ranging from 9 to $11 \mathrm{~mm} /$ year. At the level of the Cordillera Central (Fig. 2), the speed of convergence decreases from the southeast to the northwest, from 4 to $1.1 \mathrm{~mm} /$ year. Movement along the Enriquillo-Plantain-Garden fault zone may be transpressive; however, it has a larger compressive component in the east than in the west, $12 \mathrm{~mm} / \mathrm{year}$ and $10 \mathrm{~mm} /$ year, respectively. The convergence speed calculated at the Muertos thrust decreases regularly from west to east, from $7 \mathrm{~mm} /$ year in the western part to less than $1 \mathrm{~mm} /$ year to the south of Puerto Rico. There is an E-W extension between the Hispaniola and Puerto Rico blocks of 3 to $4 \mathrm{~mm} /$ year (all speeds indicated here are from Calais et al. 2016).
MT: Muertos thrust; OFZ: oriental fault zone; SBH: sub-basin of Haiti; SBD: sub-basin of Venezuela; SFZ: Septentrional Fault Zone; TH: Trans-Haitian thrusts; 1: Hispaniola; 2: Puerto Rico; 3: Jamaica; 4: Cuba

Seismic, geological and geodetic data (references provided below) thus indicate a present regime of deformation that is purely compressive at the level of the North Hispaniola subduction zone and the Muertos thrust. The deformation becomes transpressive in the Cordillera Central and to the west of Hispaniola (Trans-Haitian fault system), whereas in the upper crust of the Cordillera Oriental, the deformation might be transtensive (Fig. 2).

\section{Seismotectonic zonation}

First, a seismotectonic map was drawn, based on (i) scientific literature; (ii) geological maps of Dominican Republic at scale 1/50,000 issued by the National Geological Service of Dominican Republic (SYSMIN project 1999-2010) and of Haiti at scale $1 / 250,000$ (BME 1982-1988); (iii) the focal mechanism database of ISC-GEM and USGS, (iv) the digital earth models SRTM (Shuttle Radar Topography Mission-NASA), ASTER Global Digital Elevation 


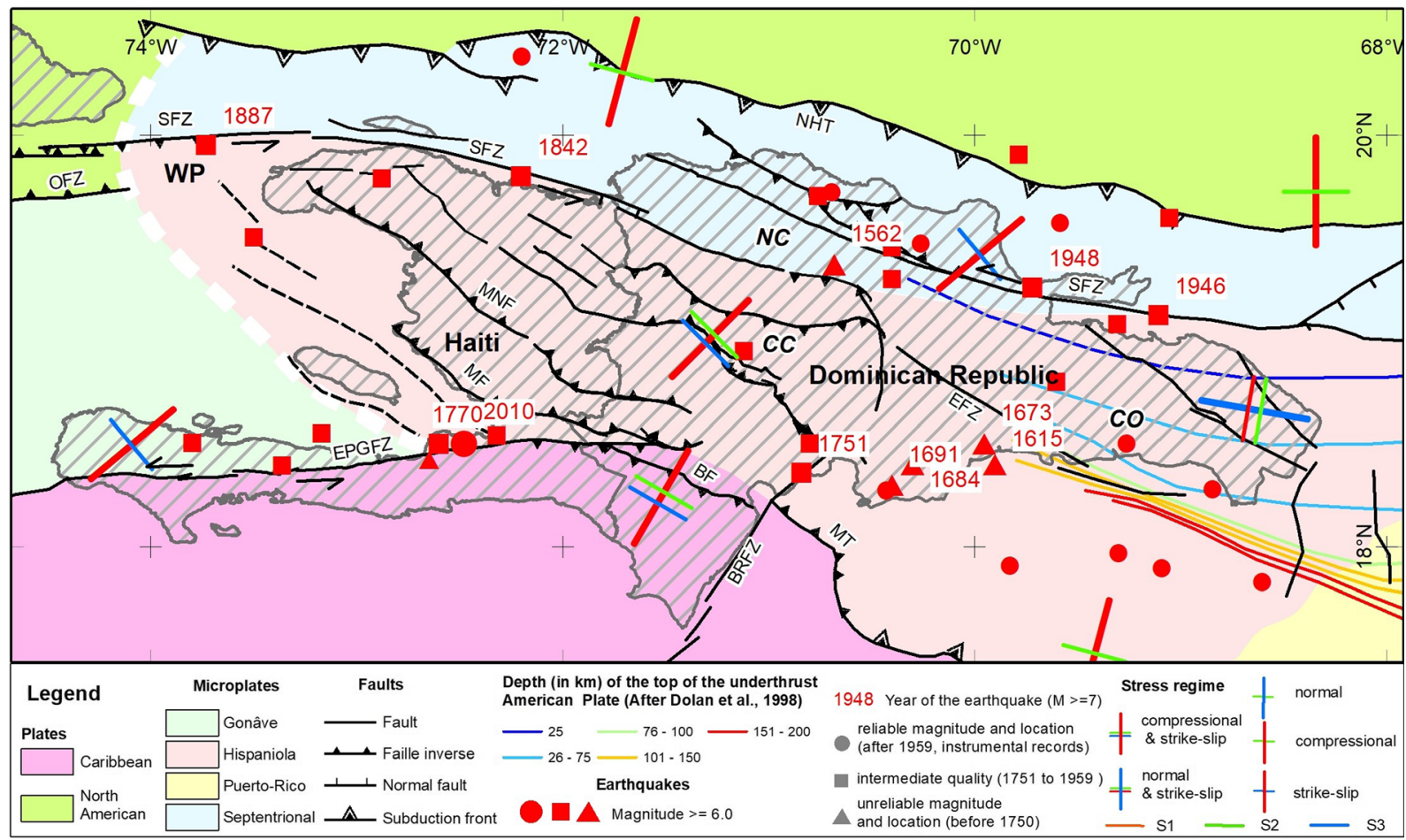

Fig. 2 Schematic representation of the different crustal microplates located in the converging North American and Caribbean plates, including the main seismotectonic features. BF, Bahoruco fault; BRFZ, Beata ridge fault zone; BwF, Bowin fault; EPGFZ, Enriquillo-Plantain-Garden fault zone; EFZ, Española fault zone;

Map (NASA) and GEBCO's gridded bathymetric data; and (v) the unified catalogue of earthquakes undertaken for this study.

Three types of faults are distinguished in Fig. 3:

1. Active fault associated with quaternary tectonic deformations or seismic records of sufficient precision to demonstrate a direct relationship with the fault".

2. Potentially active fault having (a) similarity with known active fault (proximity, same strike and dip, similar geologic evolution) or a structural relationship with an active seismic fault (as en-échelon or conjugate position); or (b) neotectonic indication (as morphostructural anomaly, geophysical discontinuity in the recent deposits, offset of the recent deposits assumed after borehole data, current movements after geodetic data etc.); or c) seismic indications (several epicentres near the fault, but without more precisions like focal mechanism or clear alignment along the trace fault).
MNF, Montagnes Noires fault; MF, Matheux fault; MR, Mona rift; MT, Muertos thrust; NHT, North Hispaniola trench; OFZ, Oriental fault zone; SFZ, Septentrional fault zone; THFS, transHaitian fault system; NC, Northern Cordillera; CO, Cordillera Oriental; CC, Cordillera Central; WP, Windward Passage

3. Other faults with no evidence to indicate present activity, according to the current scientific knowledge.

Among the active faults, are distinguished, Fig. 3: the subduction zone of the American plate (North Hispaniola Trench, NHT), the Muertos thrust (MT), the Septentrional fault zone (SFZ), the Enriquillo-PlantainGarden Fault Zone (EPGFZ), the central thrust of the Peralta belt front thrust (PBFT), the Matheux fault (MF) and the reverse fault of Bahoruco (BF). In particular among the potentially active faults are the NW-SE faults of the western peninsula of Hispaniola (Yabon Fault System, YFS and Vacama Fault, VF), and the Española Fault Zone (EFZ). The reverse NW-SE faults of the bay of Port-au-Prince or the submeridian Beata Ride Fault Zone (BRFZ) are also considered potentially active.

Second, we conducted the seismotectonic zoning of Hispaniola (Fig. 4 and Fig. 5), consisting of the identification, delineation and characterization of seismotectonic units. Each unit is characterized by current homogeneous tectonic deformation and a maximum reference 


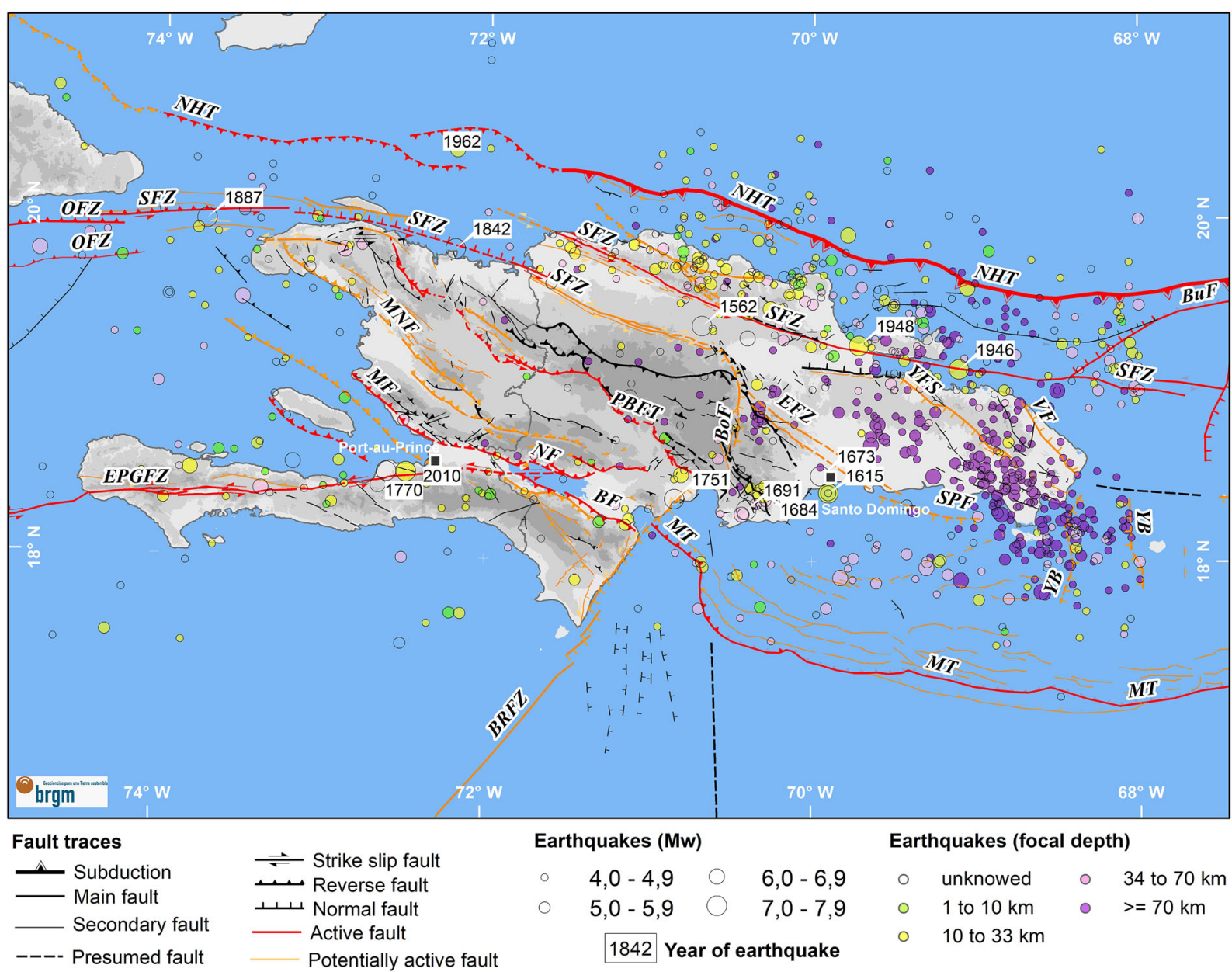

Fig. 3 Seismotectonic map of Hispaniola. BF, Bahoruco fault; $\mathrm{BoF}$, Bonao fault; BRFZ, Beata ride fault zone; BuF, Bunce fault; EFZ, Española fault zone; EPGFZ, Enriquillo-Plantain-Garden fault zone; MF, Matheux fault; MNF, Montagnes Noires fault; MT, Muertos thrust; MR, Mona rift NF, Neiba fault; NHT, North earthquake. From the geological, geophysical and seismotectonic analysis, the zoning of Hispaniola distinguishes 43 sources, divided into three types:

1. Active or potentially active faults (Fig. 4, Table 1): The main faults delimiting major structural blocks (Fig. 2). Faults can be divided into several segments, depending on their geological history, their seismic activity, their current movement and the geometry of the fault plan. The relative motion of faults was deduced from GPS measurements, deformation models, paleoseismic data or morphological information. The maximum possible magnitude of earthquake was estimated from the empirical relationships of Wells and Coppersmith (1994), taking into account the maximum length and the width of the
Hispaniola trench; OFZ, Oriental fault zone; PBFT, Peralta belt front thrust; PRT, Puerto Rico trench; SFZ, Septentrional fault zone; SPF, San Pedro fault; VF, Vacama fault; YB, Yuma basin fault system; YFS, Yabon fault system

considered fault segment. These assessments were compared to maximum magnitudes calculated for historical earthquakes.

2. The Muertos thrust (Fig. 4, Table 2) and the subduction zone of the North American plate under the Caribbean plate (Table 3). The proposed segmentation depends on both the dip and the depth of the fault plane, as well as the sliding rate.

3. The seismogenic areas (Fig. 5, Table 4): It concerns crustal domains generally bounded by major active shear zones. Some are characterized by a diffuse deformation, associated with infrequent seismicity and low magnitude (example, Unit 10, Beata Ridge, seismic background 5.0). These areas could be cross-cut by sub-parallel faults with similar geodynamic characteristics (for example, internal 
thrusts within the Cordillera Central, zone A7, or reverse faults located behind the Muertos thrust front, zone A1).

\section{The Muertos thrust and the thrusting block of Muertos}

Among the main active or potentially active faults of Hispaniola, the Muertos fault corresponds to the thrust of the Hispaniola and Puerto Rico blocks over the Caribbean plate (Fig. 2). The total length of the system is close to $700 \mathrm{~km}$, with the main plane composed of several segments of up to $170 \mathrm{~km}$ in length. The depth of the thrust plane ranges from $40 \mathrm{~km}$ to the west, to only $20 \mathrm{~km}$ to the east (Granja Bruña et al. 2009, 2010, 2014).

The Muertos thrust (MT) is structured in different segments, characterized by speed, geometry of the fault plane (orientation, dip) and specific deformations (Fig. 4, Table 1). The limit between the segments MT-Punta Salinas (MT-PS) and MT-Centre West (MT-CW) corresponds to the inflexion of the thrust plane by the Beata crest. The MT-Centre East (MT-CE) segment is characterized at the thrust front by the presence of normal faults (Granja Bruña et al. 2009). These disappear on both sides of the MT-CE segment. Plate kinematic models indicate a convergence rate decreasing from west to east (Benford et al. 2012). These data are consistent with the decrease of the underwater relief directly above the thrust plane. According to Symithe et al. (2015) and Calais et al. (2016), the mean rate is estimated at $6.9 \mathrm{~mm} /$ year for the westernmost segment (MTPS), 6.2 for the MT-CentreWest segment, 4.6 for the MT-CentreEast segment, and 0.8 for the easternmost segment (MT-E). The epicentre of the October 18, 1751, earthquake, magnitude estimated at more than 7.0 (Bakun et al. 2012), is located along the Bahia de Ocoa coast, near the western boundary of the MT-PS thrust segment and along the normal fault of the Beata Ridge fault zone (Fig. 3). This earthquake could have been caused by the Muertos thrust.

According to seismic profiles and earthquake focal mechanisms, as well as gravimetric models (Granja Bruña et al. 2009, 2014), the dip of the thrust plane, from approximately $12^{\circ}$ in the front, increases towards the north up to $30^{\circ}$ at a depth of approximately $22 \mathrm{~km}$.
The break-slope of the thrust plane is observed at a depth of around 6-7 km. On this basis, for each thrust segment, two seismotectonic entities were identified (Fig. 4, Table 2): near sources (MT1, MT3 and MT5) and distant sources (MT2, MT4 and MT6).

Secondary out-of-sequence thrusts deeply linked to the main plane characterize the frontal zone of the thrust compartment (Fig. 6, A1). The zone behind the front (Fig. 6, A2) is exposed to extensive deformations. These can be interpreted as normal faults in the leading anticline of the hanging block. The boundary between zones A1 and A2 is traced on the basis of analysis of bathymetric and seismic data reported by Granja Bruña et al. (2014). The northern boundary of zone A2 corresponds to a major magnetic anomaly (Maus et al. 2008). This geophysical anomaly could mark the rooting of the Hispaniola plate at this location. The earthquake of 24th June 1984 (Mw 6.7) was recorded at a depth of $35 \mathrm{~km}$ in the San Pedro basin (Fig. 2). Its focal mechanism is purely reverse over the subequatorial plane (Byrne et al. 1985). This earthquake probably marked the sudden deepening of the rooting of the Muertos thrust under the Hispaniola block.

\section{The Beata Ridge}

The Beata Ridge (Fig. 1) is an underwater morphologic structure about $450 \mathrm{~km}$ in length. It separates the Colombia Basin, to the west, from the Venezuela Basin, to the east. It is formed of a thick Caribbean oceanic crust, constituted essentially of intrusive rocks (gabbros and dolerites) from the Late Cretaceous. Seismic refraction profiles indicate a thickness of close to $20 \mathrm{~km}$ at the level of the Beata Ridge (Ewing et al. 1960; Edgar et al. 1971; Case et al. 1990), 10 to $15 \mathrm{~km}$ to the east in the Dominican sub-basin, and only 5 to $10 \mathrm{~km}$ in the Haitian sub-basin (Mauffret and Leroy, 1997). The limits of zone A4 and the Beata Ridge (Fig. 5, Table 4) overlap with those of a positive magnetic axis (Maus et al. 2008).

The recess of the Beata Ridge under the Hispaniola block from the Neogene (Mercier de Lépinay et al. 1988; Hernaiz Huerta and Pérez-Estaún 2002) gave rise to a virgation in the frontal Muertos thrust and the Peralta belt (Fig. 2). The Bahoruco thrust is interrupted to the east at the Beata Ridge. At this location, a distinct topographic line marks the coast of Hispaniola. This 


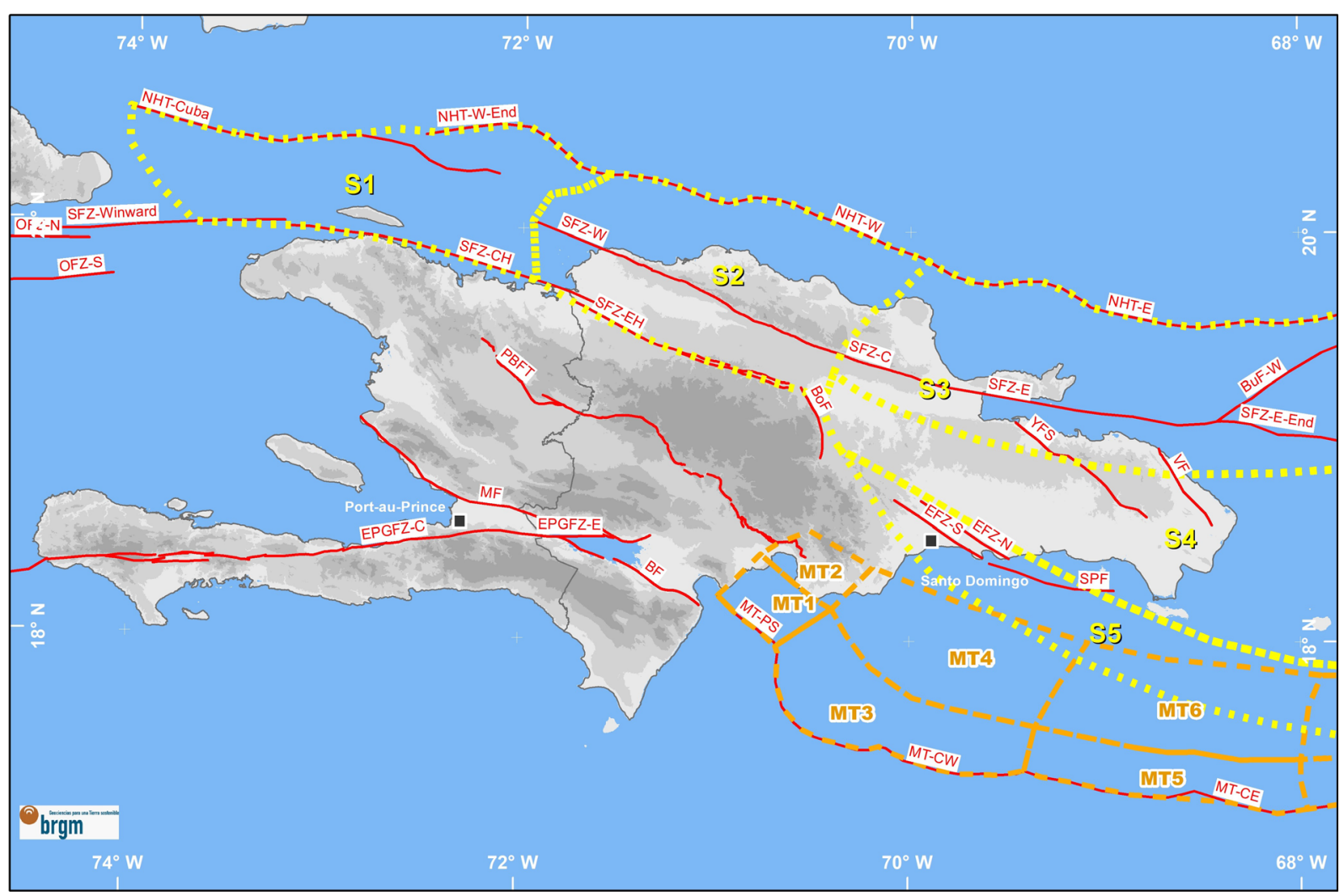

Fig. 4 Seismogenic structures of Hispaniola: major active or potentially active fault traces (in red), Muertos thrust plan segments (in orange), division of the North American plate subduction (in yellow) (cf. Tables 1, 2, 3)

relief is guided by the $\mathrm{N} 40^{\circ}( \pm 5)$ of the Beata Ridge Fault Zone (BRFZ, Fig. 3).

The intersection zone between the Muertos thrust and the Beata Ridge (Fig. 5, Table 5, A3) is subject to compression under maximum horizontal stress in the NE-SW direction. Deformation is caused by NW-SE trending reverse faults and NE-SW trending normal to sinistral strike-slip faults. The former are linked to the Muertos fault system (MT, Fig. 3), whereas the latter corresponds to the Beata Ridge Fault Zone (BRFZ, Fig. $3)$.

\section{The North Hispaniola Trench and the subduction plane of the North American plate}

The Puerto Rico Trench (PRT) and Nord-Hispaniola Trench (NHT or North Hispaniola fault) systems shown in Fig. 2 mark the boundary between the subducted North-American Plate on one side, and the Puerto Rico, Septentrional, and Hispaniola blocks on the other side. They accommodate the convergence between the Hispaniola and Caribbean Plates with the North American Plate, whereas the Septentrional Fault System and the EnriquilloPlantain-Garden Fault System accommodate a significant part of the lateral motion.

Seismicity recorded at the level of the North Hispaniola Fault is particularly intense in the eastern part of the system, but decreases rapidly towards the west (Fig. 3). The earthquake of August 4, $1946(\mathrm{Mw}=7.8( \pm 0.5)$, ISC-GEM 2013) is the strongest recorded earthquake associated with this fault zone. The earthquake of the 2nd of December 1562 (epicentral intensity Io = IX and magnitude estimated at 7.7), at the origin of the destruction of the town of Santiago (Fig. 2), may itself be linked to the North Hispaniola fault system.

The North Hispaniola fault system is divided into several segments, depending on the geometry of the interface of the subduction zone, the seismicity, and the depth of the slab (Fig. 4, Table 3). The eastern North Hispaniola segment (NHT-E) is localized between the Mona Rift and the eastern Hispaniola peninsula. This segment is characterized by intense seismic activity 


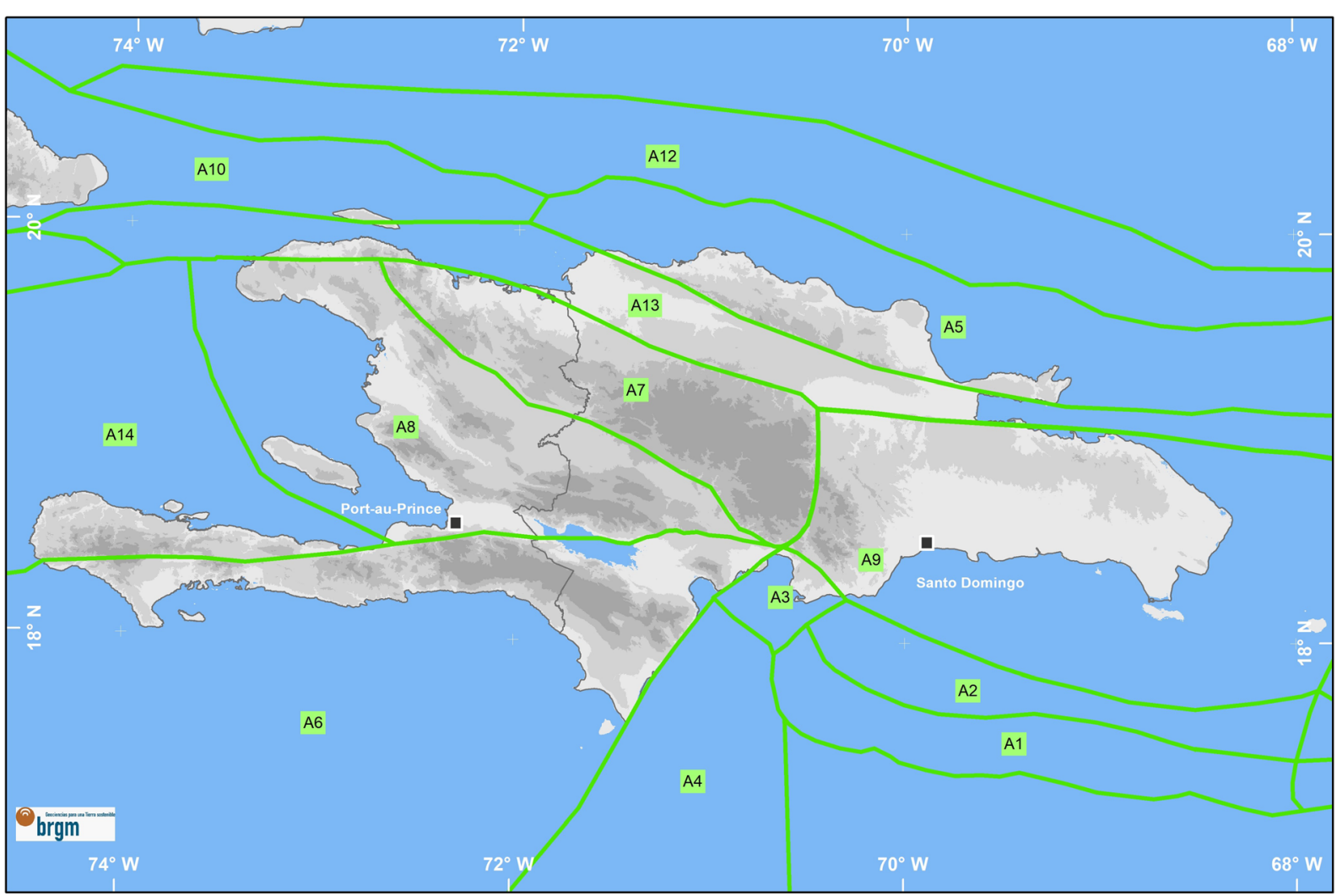

Fig. 5 Seismogenic areas of Hispaniola (cf. Table 4)

(Fig. 3) and a rapid deepening of the subduction plane (Fig. 2). The focal depth of earthquakes reaches over $200 \mathrm{~km}$ directly under the Española fault zone.

To the west, at the level of the western segment (NHT-W), seismic activity diminishes rapidly. Earthquakes have a focal depth under $50 \mathrm{~km}$. However, the earthquake of April 20, 1962 (Mw 6.6) is located along the NHT-W. Based on marine geophysical data, Dillon et al. (1992) describe folds and spaced thrusts in sedimentary cover on the North coast of Hispaniola. More to the west, Calais and Mercier de Lepinay (1991) and Rodríguez-Zurrunero et al. (2020) describe other numerous compressive structures between the Winward Passage and the NE margin of Cuba. Corbeau et al. (2019) indicate an almost pure reverse focal mechanism of earthquakes in the Winward Passage. Based on geophysical, seismic and geodetic data, Rodríguez-Zurrunero et al. (2020) distinguish two tectonic structures due to the collision process at the western end of the NHT: a positive flower structure in the Winward Passage and an imbricate fold (linked to the NHT-Cuba, Fig. 4) and thrust system along the NE margin of Cuba.
According to Benford et al. (2012), the displacement rate along the North Hispaniola Fault decreases progressively from east to west, from 6.5 to $5.3 \mathrm{~mm} /$ year at the level of NHT-E, to $3.8 \mathrm{~mm} /$ year at the level of the NHTCuba segment. Conversely, for Calais et al. (2016), the motion along the North Hispaniola Fault shows a slight increase from east (on the order of $2.4 \mathrm{~mm} /$ year) to west (close to $3.6 \mathrm{~mm} /$ year). Whatever the authors, their models show a significant decrease of the subduction movement from east to west, from the Puerto Rico Trench to the North Hispaniola Trench. At the west of the Mona Rift, plate movement is mainly accommodated by the Septentrional Fault Zone, where the rate is close to $10 \mathrm{~mm} /$ year.

The North Hispaniola block (A5, Fig. 5, Table 4) comprises the Septentrional Range and the Samana Peninsula, situated in the Dominican Republic. It is an ancient accretionary prism deformed by tectonic collision in the Late Cretaceous and Cenozoic. Its petrographic collection includes high-pressure metamorphic rocks (blue shale, eclogite) and fragments of the protoCaribbean lithosphere (ophiolites). The boundaries of the A5 zone are as follows: to the north, the subduction 


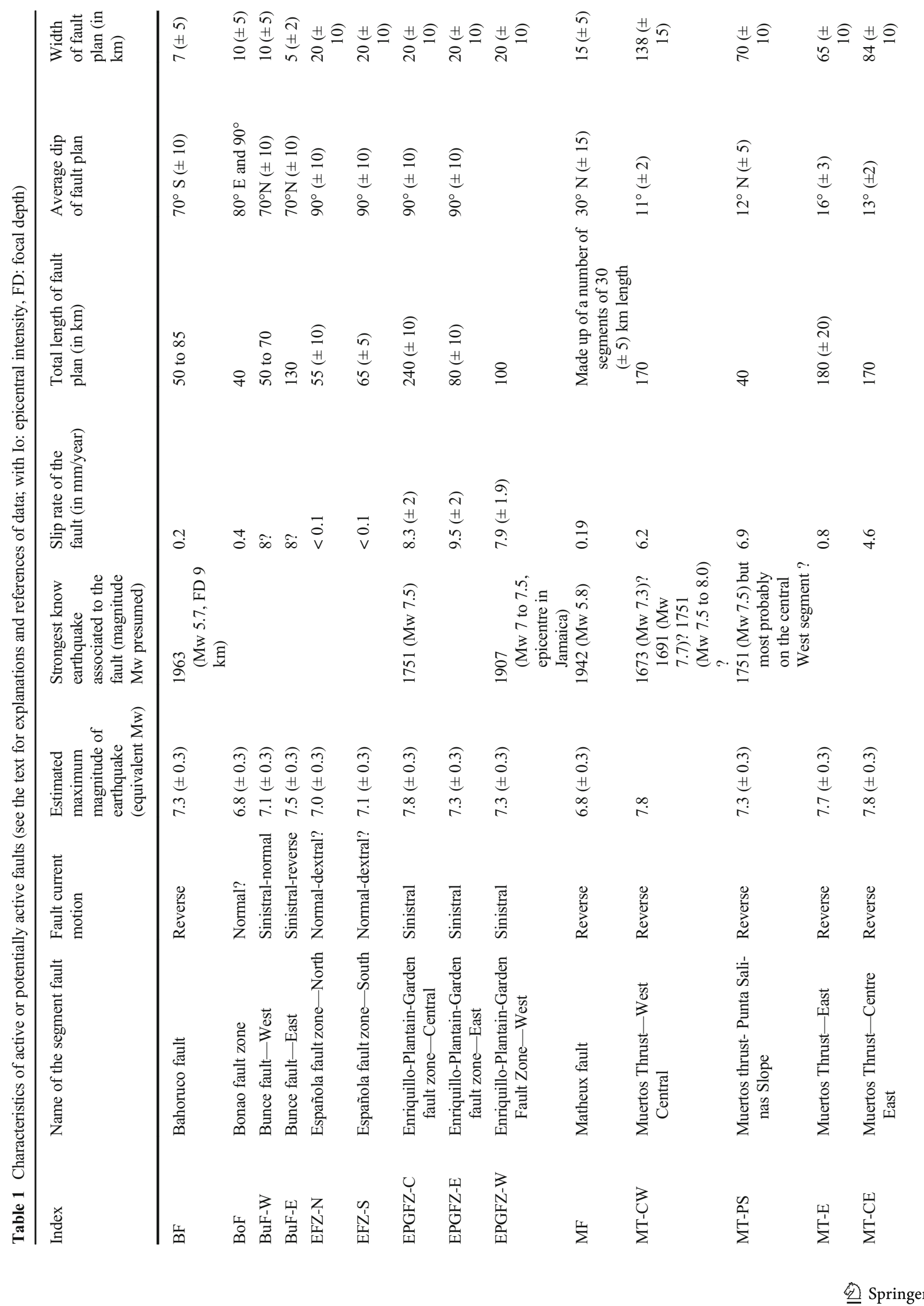




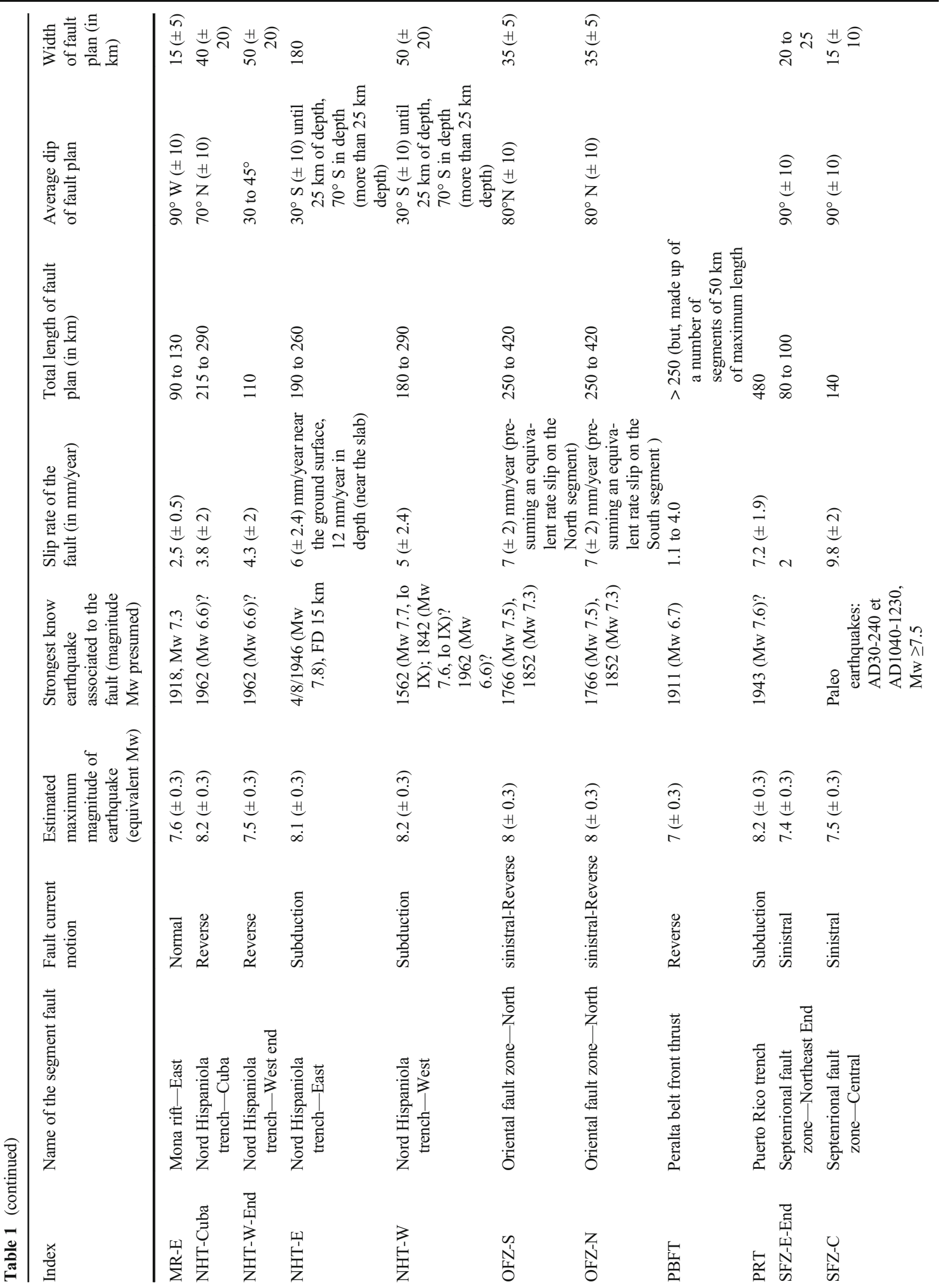




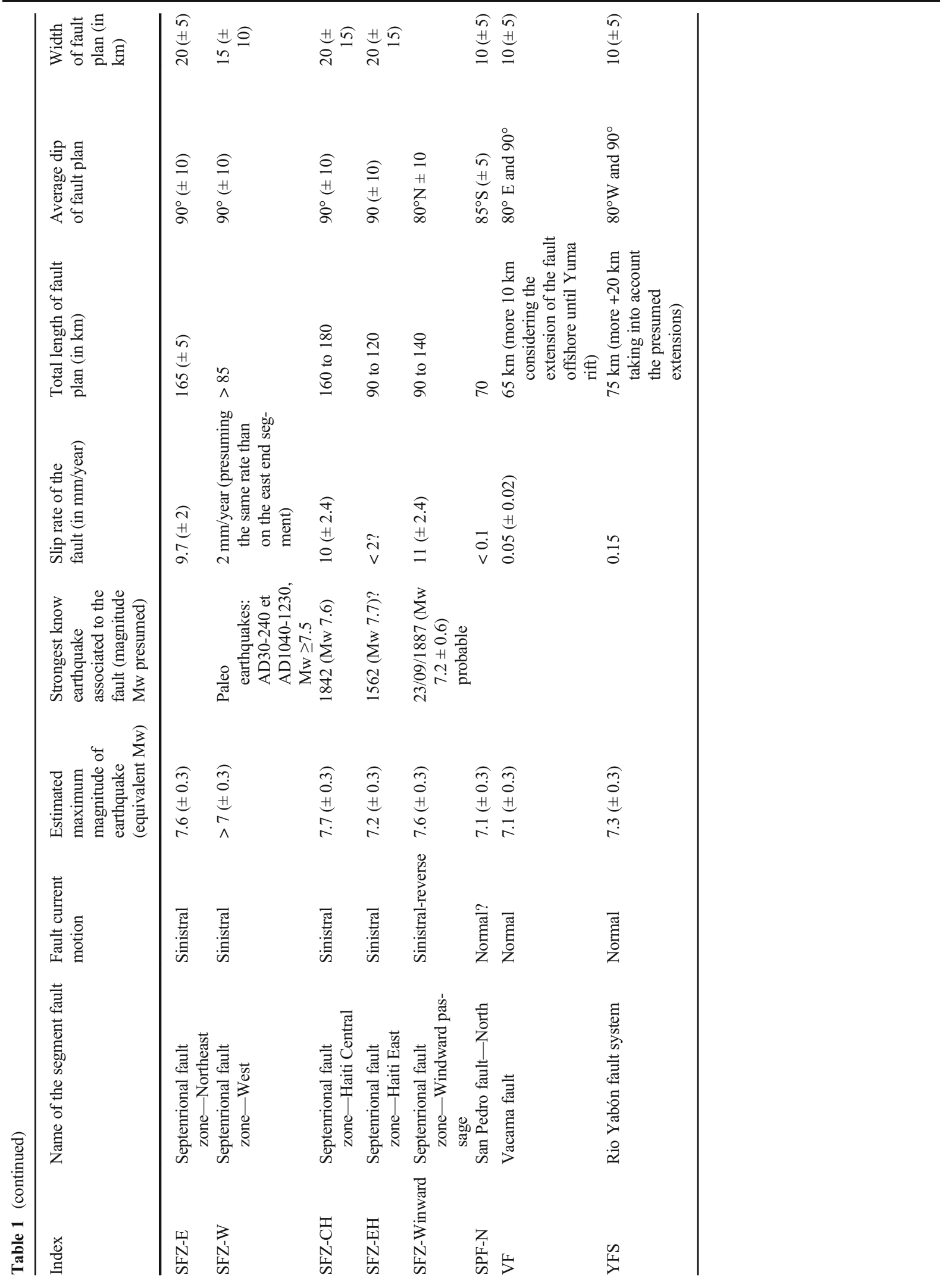


Table 2 Characteristics of the segments of the Muertos Thrust Plane (cf. Fig. 4)

\begin{tabular}{lllll}
\hline No. & Name & Min-max depth $(\mathrm{km})$, dip angle & Slip rate (mm/year) & Maximum magnitude (Mw) \\
\hline MT1 & MT-Punta Salinas-shallow & D 0-7 km, Dip 2 ${ }^{\circ}$ & 6.9 & $7.3( \pm 0.3)$ \\
MT2 & MT-Punta Salinas-deep & D 7-35 km, Dip 42 ${ }^{\circ} \mathrm{N}$ & 6.9 & $7.3( \pm 0.3)$ \\
MT3 & MT-Centre West-shallow & D 0-7 km, Dip 11 $\mathrm{N}$ & 6.2 & $7.8( \pm 0.3)$ \\
MT4 & MT-Centre West-deep & D 7-40 km, Dip 30 N & 6.2 & $7.8( \pm 0.3)$ \\
MT5 & MT-Centre East-shallow & D 0-6 km, Dip 13 N & 4.6 & $7.8( \pm 0.3)$ \\
MT6 & MT-Centre East-deep & D 6-40 km, Dip 34 ${ }^{\circ} \mathrm{N}$ & 4.6 & $7.8( \pm 0.3)$ \\
\hline
\end{tabular}

trench of the North American plate (NHT), to the south, the Septentrional sinistral shear band (SFZ), and to the East, the Mona Rift. To the west of longitude $72^{\circ} \mathrm{W}$, zone A10 (Fig. 5), compressive tectonics is less, but still, present). In depth, the A5 zone is limited by the subduction zone of the North American plate.

The A12 zone (named Subduction front and Bahamas platform) is situated in front of the Hispaniola Trench. It forms the Hispaniola basin and the calcareous plateau of the Bahamas, showing a flat morphology, but with a progressive folding and faulting of the sediments towards the south (Dillon et al. 1992). The strongest recorded earthquakes are of a magnitude less than 6.0.

\section{The Septentrional Fault Zone}

The Septentrional fault zone is a shearing zone accommodating the sinistral component of the motion of the Caribbean and North American plates (SFZ, Fig. 2 and Fig. 3). It is located to the north of Hispaniola and extends close to $600 \mathrm{~km}$, between the Windward Passage to the west, and the Mona Graben to the east. Its direction is E-W at the level of the Windward Passage, becoming WNW-ESE to the east. To the south of Cuba, the Oriental Fault Zone (0FZ, Fig. 1 and Fig. 2). is also an important sinistral shear zone. The latter prolongs the Septentrional fault zone to the west and constitutes the boundary between the North American plate and the Caribbean plate.

The SFZ is composed of two branches. The west branch crosses the Windward Passage, between Cuba and Haiti, continues towards Tortuga Island, along the Haitian coast, and borders the south of the Neogene basin of Cibao in the Dominican Republic. The east branch forms the northern boundary of the Cibao basin and extends towards the east, from the south of the Septentrional Range to the Mona Rift. Following the focal mechanism and the focal depth of earthquakes, the SFZ plane extends by a depth of 20-25 km until its intersection with the subduction plane of the American plate (Dolan et al. 1998).

Each of the two branches of the SFZ is composed of several fault segments (Fig. 4, Table 1). To the west, the SFZ-Windward segment shows transtensive deformation (Calais and Mercier de Lepinay 1991). It is likely associated with the earthquake of September 23, 1887, Io = IX, estimated Mw 7.8 (Ali et al. 2008) or Mw 6.7 (ten Brink et al. 2011), (Fig. 2 and Fig. 3). Further north along the Haitian coast, the SFZ-CH segment (Centre Haiti) is very likely at the origin of the 7th of May 1842 earthquake, Io = IX to IX-X and estimated Mw 7.6 (ten Brink et al. 2011). This earthquake was violently felt between the two cities, Santiago-de-los-Caballeros in the Dominican Republic and Môle-Saint-Nicolas in the northwest of Haiti (Flores et al. 2011), i.e. over a

Table 3 Characteristics of the segments of the North American plate subduction plane (cf. Fig. 4)

\begin{tabular}{lllll}
\hline Name & Fault trace & Min/max depth $(\mathrm{km})$ & Dip angle $\left({ }^{\circ}\right)$ & Estimated maximum magnitude $(\mathrm{Mw})$ \\
\hline S1 & NHT-Cuba & $0-50$ & $45( \pm 10) \mathrm{S}$ & 7.5 \\
S2 & NHT-W & $0-50$ & $30( \pm 10) \mathrm{S}$ & $8.2( \pm 0.3)$ \\
S3 & NHT-E & $0-25$ & $17( \pm 2) \mathrm{S}$ & $8.1( \pm 0.3)$ \\
S4 & NHT-E & $25-100$ & $55^{\circ}( \pm 5) \mathrm{S}$ & 7.8 \\
S5 & NHT-E & $100-200$ & $70^{\circ}( \pm 10) \mathrm{S}$ & \\
\hline
\end{tabular}


Table 4 Characteristics of the superficial seismotectonic areas in Hispaniola (cf. Fig. 5)

\begin{tabular}{|c|c|c|c|c|}
\hline Number & Name & Tectonic regime & Orientation of the faults & $\begin{array}{l}\text { Maximum } \\
\text { magnitude }(\mathrm{Mw})\end{array}$ \\
\hline A1 & $\begin{array}{l}\text { Western mountain range of } \\
\text { Muertos thrust }\end{array}$ & Compressive & $\begin{array}{l}\text { WNW-ESE faults, reverse motion, } \\
\text { length } 50 \text { to } 90 \mathrm{~km}\end{array}$ & M $7.0( \pm 0.3)$ \\
\hline $\mathrm{A} 2$ & $\begin{array}{l}\text { Behind the Western mountain } \\
\text { range of Muertos thrust }\end{array}$ & $\begin{array}{l}\text { Extensional at surface, } \\
\text { compressive at depth } \\
(10 \text { to } 15 \mathrm{~km})\end{array}$ & $\begin{array}{l}\text { Small normal faults, } \\
\text { WNW-ESE trend at the surface }\end{array}$ & $\begin{array}{l}\text { M } 5.0 \text { up to } 7( \pm \\
\text { 2) km depth, } \\
\text { then M } 7.8( \pm \\
0.3)\end{array}$ \\
\hline A 3 & $\begin{array}{l}\text { Muertos Thrust end Northern } \\
\text { end of Beata crest }\end{array}$ & $\begin{array}{l}\text { Compressive } \\
\text { (NNE-SSW) }\end{array}$ & $\begin{array}{l}\text { NW-SE, reverse; } \\
\text { NE-SW to NNE-SSW, normal sinistral }\end{array}$ & M $7.0( \pm 0.3)$ \\
\hline A4 & Beata crest & $\begin{array}{l}\text { Transpression } \\
\text { (NNE-SSW) }\end{array}$ & NNE-SSW, normal sinistral & M 5.0 \\
\hline A5 & North Hispaniola Block & Transpression (NE-SW) & WNW-ESE to NW-SE, reverse sinistral & M $7( \pm 0.3)$ \\
\hline A6 & $\begin{array}{l}\text { Bahoruco, Hotte and Selle } \\
\text { massifs }\end{array}$ & Compressive & NW-SE, reverse & M 5.5 \\
\hline A7 & $\begin{array}{l}\text { Central mountain-Hispaniola } \\
\text { Block }\end{array}$ & Transpression (NE-SW) & $\begin{array}{l}\text { WNW-ESE to NW-SE, reverse sinistral; } \\
\text { NNE-SW, dextral }\end{array}$ & M $7.0( \pm 0.3)$ \\
\hline A8 & Trans-Haitian thrusts & Compressive & NW-SE to NNW-SSE, reverse-sinistral & M 6.8 \\
\hline A9 & The eastern Peninsula & $\begin{array}{l}\text { Extensional, } \\
\text { strike-slip }\end{array}$ & $\begin{array}{l}\text { WNW-ESE to NW-SE, dextral to normal; } \\
\text { NNE-SSW to NE-SW, sinistral to normal }\end{array}$ & M 7.0 \\
\hline A10 & Cuba continental platform & Transpression & $\mathrm{E}-\mathrm{W}$ & M 6.5 \\
\hline A11 & Mona rift & Extensional & NS to NNE-SSW, normal & M 7.5 \\
\hline A12 & $\begin{array}{l}\text { Subduction front and Bahamas } \\
\text { platform }\end{array}$ & Compressive & WNW-ESE & M 6.5 \\
\hline A13 & $\begin{array}{l}\text { Winward trench, Ciabo and } \\
\text { Samaná basins }\end{array}$ & Strike-slip & EW to WNW-ESE & M 7.0 \\
\hline A14 & Gonave Block & Transpression & NE-SW to the West part of the area? & M 6.0 \\
\hline
\end{tabular}

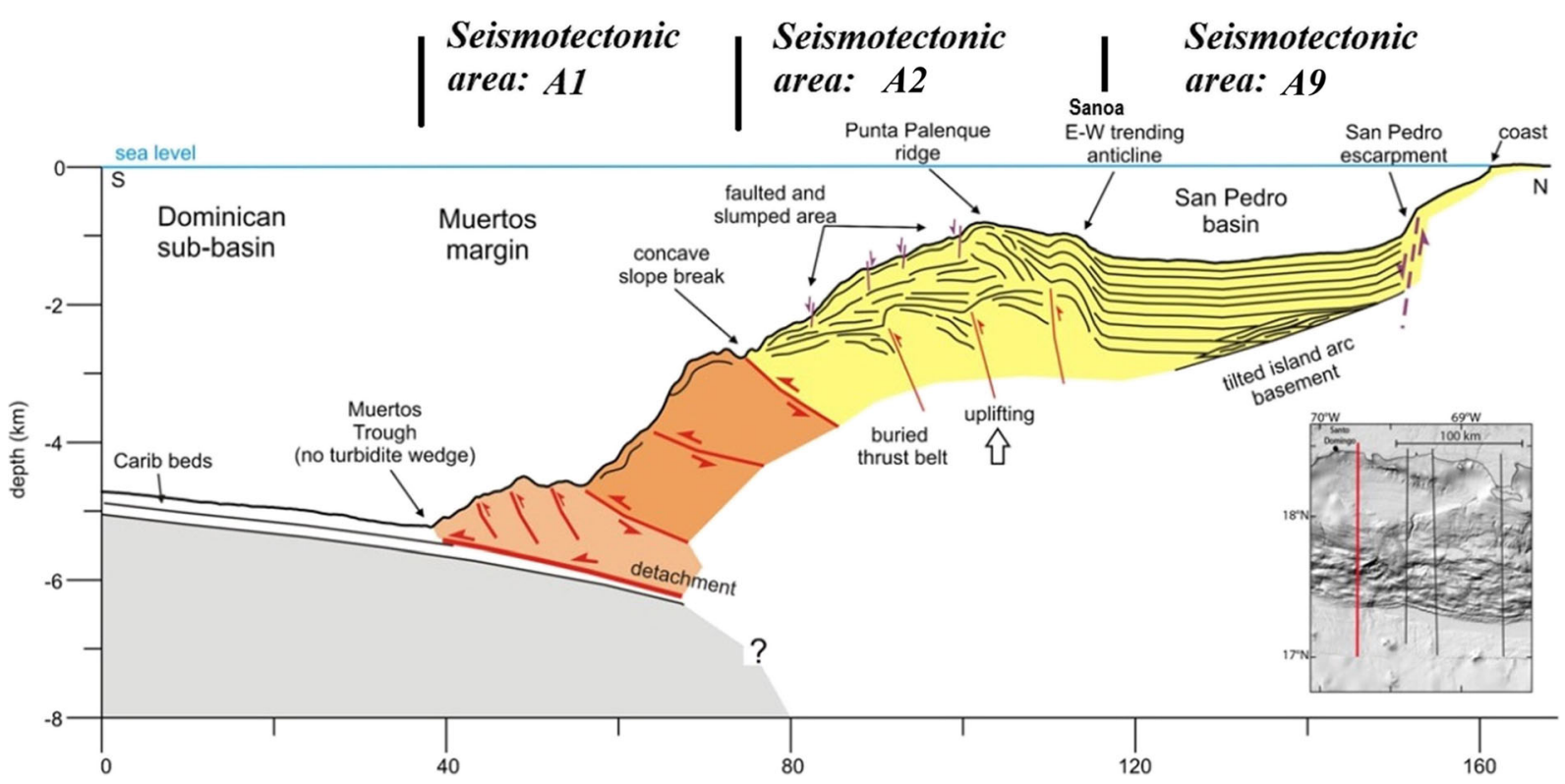

Fig. 6 Limit of seismotectonic domains defined at the hanging wall block of Muertos thrust (cross section after from Granja Bruña et al. 2014, modified) 
distance of approximately $300 \mathrm{~km}$. Off the coast of the city of Cap-Haitien, offset channels are described above the SFZ-CH segment (Leroy et al. 2015; Corbeau 2015). They show a cumulated displacement of $16.5 \mathrm{~km}$. If we assume that the current displacement of 9 to $9.8 \mathrm{~mm} /$ year, calculated from GPS measurements (Benford et al. 2012), remained stable during the Quaternary, a cumulated displacement of $16.5 \mathrm{~km}$ indicates that the fault has been active since approximately $1.8 \mathrm{Myr}$ (Corbeau 2015). To the east, where the SFZ-EH segment (East Haiti) has low activity, the deformation is then taken over by the north branch of the Septentrional Fault Zone. The epicentre of the December 2, 1562, earthquake, situated along the SFZ-EH axis, may be related to this fault. However, no trace of this earthquake was found during paleoseismic studies along the Septentrional fault zone (Prentice et al. 2003). According to these authors, the 1562 earthquake was more likely due to the movement of the North Hispaniola Trench.

Paleoseismic trenches dug along the central segment of the Septentrional fault zone (SFZ-C) reveal at least two paleoseismic surface breaks, dated between 30 and 40 years B.C. and between 1040 and 1230 B.C. (Prentice et al. 2003). In one trench, the fracture shows a surface displacement of $5( \pm 0.5) \mathrm{m}$, which corresponds to a magnitude Mw 7.4 to 7.5 earthquake, using the empirical relationships of Wells and Coppersmith (1994). Moreover, the offsets observed in morphological objects (terraces, talwegs) suggest a mean slip rate of 6 to $12 \mathrm{~mm} /$ year along the SFZ-C. Prentice et al. (2003) estimated a return period of 800 to 1200 years for earthquakes of magnitude above 7.0 along this segment of SFZ. Based on the last paleoseismic event dating from over 800 years ago, Prentice et al. (2003) underlined the very high probability of occurrence of a large-scale earthquake along the east branch of the Septentrional Fault.

Paleoseismic data and offsets of underwater morphological features provide speeds consistent with geodetic measurements (Mann et al. 2002; Manaker et al. 2008; Benford et al. 2012; Calais et al. 2016). The mean displacement speed of the SFZ is estimated between 9 and $11 \mathrm{~mm} /$ year.

\section{The Enriquillo-Plantain-Garden fault zone}

The Enriquillo-Plantain-Garden fault zone (EPGFZ; Fig. 2 and Fig. 3) surrounds the south peninsula of Haiti
(Mann et al. 1995; Corbeau et al. 2016; Wessels et al. 2019). To the west, this fault system reaches the island of Jamaica (Plantain-Garden valley) and connects to the Walton fault system. To the east, the EnriquilloPlantain-Garden Fault Zone ends at the level of the Enriquillo depression. The deformation is replaced by the reverse faults of Neiba (NF) and Bahoruco (BF). Recent high-resolution bathymetric campaigns and seismic reflection profiles show that this structure is not inherited from anterior tectonic phases, but from a major sinistral shear that took place in the Late Miocene (Leroy et al. 2015; Corbeau et al. 2016).

Geodetic measurements indicate a transpressive deformation along the Enriquillo-Plantain-Garden fault zone, with an increasing compressive component from the west of the Haitian peninsula to Lake Enriquillo (Benford et al. 2012; Calais et al. 2016). In the alluvial plain and marine gulf of Port-au-Prince, the reverse component is mainly accommodated by NW-SE reverse faults observed in the field or by seismic data analysis (Mann et al. 1995; Terrier et al. 2014; Saint Fleur et al. 2015; Wessels et al. 2019).

The January 12, 2010 earthquake reached a magnitude of $\mathrm{Mw} 7.0$. Its focal depth was $15 \mathrm{~km}$. The epicentre was located about $20 \mathrm{~km}$ to the east of the centre of Port-au-Prince (Fig. 2). The earthquake involved two distinct faults with previously reverse oblique faults instead of the main strike-slip EPGFZ (Calais et al. 2010; Mercier de Lepinay et al. 2011; Saint Fleur et al. 2015). The 2010 earthquake was clearly in the context of oblique convergence described in the region of Port-au-Prince.

Other major historical earthquakes are known along this structure (Fig. 2), including the earthquakes of 09/ 11/1701-Io VII, estimated Mw 6.6 (Bakun et al. 2012); 21/11/1751-Io VIII, estimated Mw 6.6 (Bakun et al. 2012); 03/06/1770 - Io X (Sisfrance Antilles, 2009), estimated Mw 7.5, 08/04/1860-Io VII, estimated Mw 6.3 (Bakun et al. 2012); and 28/10/ 1952, Io IX, estimated Mw 6.2 (ISC-GEM 2013). Several geomorphic evidence of youthful faulting are described along the EPGFZ, with some of the offsets suggesting co-seismic displacement with an earthquake of magnitude between Mw 7.0 and 7.6 (Prentice et al. 2010).

According to DeMets and Wiggins-Grandison (2007), the movement along the Enriquillo-PlantainGarden fault zone in Jamaica is about $7 \mathrm{~mm} /$ year. Benford et al. (2012) provided more precision on these 
results, indicating a left lateral motion of $5.5( \pm 0.5) \mathrm{mm} /$ year, and $3( \pm 0.5) \mathrm{mm} /$ year convergence, along the Plantain-Garden Fault segment, in the Morant Trough. To the east, in the Haitian peninsula, the current movement along the Enriquillo-Plantain-Garden fault zone increases to reach 9 to $10 \mathrm{~mm} /$ year (Benford et al. 2012; Calais et al. 2016).

The Enriquillo-Plantain-Garden Fault Zone consists of three main segments (Fig. 4, Table 1). The eastern segment (EPGFZ-E) extends from the east of Enriquillo Lake towards Port-au-Prince, as far as longitude $72^{\circ} \mathrm{W}$. The focal mechanism of the earthquakes calculated in this region (Rodriguez et al. 2018) is consistent with a NE-SW direction of maximal horizontal stress. The EPGFZ-E trace interfered with multiple NW-SE folds and reverse faults. At the level of Lake Enriquillo, the trace of the fault zone is uncertain; this interpretation is based on Holocene morphological structures (tilting of alluvial terraces, topographic rises, change in stream axis) and a major magnetic anomaly (García-Senz 2004). According to Symithe and Calais (2016), after geodetic data, the EPGFZ-E segment would be a north dipping oblique reverse fault system. Between Port-auPrince and the western tip of the Haitian peninsula, the EPGFZ-C (Central) segment, of mean direction $\mathrm{N} 80^{\circ} \mathrm{E}$, limits the southern extension of northwest trending reverse faults. The EPGFZ-C segment is at the origin of the 2010 earthquake and several other major earthquakes (Fig. 2). To the west, offshore, in the Jamaica passage, the EPGFZ-W (West) segment is a complex structure. It has split into several parallel faults, and pressure ridges, restraining bends, and horsetail splays are present (Corbeau et al. 2016).

\section{The Cordillera Central and the Trois-Rivières-Péralta thrust}

The Cordillera Central (Fig. 2) is a structurally complex range, extending over $300 \mathrm{~km}$ from the northwest part of Haiti toward the southeast in the centre part of the Dominican Republic, with a mean width of 50 to 60 $\mathrm{km}$. According to gravimetric data, the crustal thickness in the eastern part of Hispaniola is $\pm 30-35 \mathrm{~km}$ (Granja Bruña et al. 2010). We assume it has a similar thickness to the Cordillera Central. From North to South, it displays peridotites of the Caribbean oceanic plate from the Late Jurassic, evidence of the first period of the construction of the basaltic Caribbean plateau (basic to ultra basic Duarte volcanic complex) from the Jurassic to the Early Cretaceous, then evidence of the Caribbean arc of the Late Cretaceous (Tireo formation, with mainly andesite lava flows, and large tonalite-diorite or granite intrusions) (Lewis et al. 2002; Escuder Viruete et al. 2007, 2008; García-Lobón and Ayala 2007; PérezEstaún et al. 2007).

On the south face of the Cordillera Central are the folds and thrusts of the Peralta belt, it concerns terrains corresponding to flysch of the Late Cretaceous to the Oligocene, deposited in a back-arc basin. The front of the Peralta belt is the Peralta belt fault thrust (Fig. 3, PBFT), originated in the Eocene and which thrusts over the Plio-Pleistocene formations of the Azua basin (Gomez 2004). In the Plio-Pleistocene, the Beata Ridge collided with the thrust belt, leading to the separation between the Muertos and the Peralta thrust belts. This also contributed to the rise of the Cordillera Central (Hernaiz Huerta and Pérez-Estaún 2002).

As a simplification for zoning purposes, the Central Cordillera seismotectonic zone (A2,) integrates the Peralta belt and the older Tireo formation (Upper Cretaceous volcanic-clastic rocks) located to the north and thrusting over the formations of the Peralta belt at the level of the San Juan-Restauracion Fault Zone (Hernaiz Huerta and Pérez-Estaún 2002).

The earthquake of October 6, 1911, of epicentral intensity estimated at IX (SisFrance Antilles 2009), and magnitude close to Mw 6.7 was likely caused by movement of the PBFT (Fig. 2). According to geodetic data, Calais et al. (2016) interpreted a compressive movement in the NE-SW direction, for the central zone of Hispaniola, with a decreasing rate of motion from the southeast to the northwest $(5.3 \mathrm{~mm} /$ year to $1.1 \mathrm{~mm} /$ year) distributed on the active reverse Trans-Haitian Fault System and the Cordillera Central (Fig. 2).

The seismotectonic zone of the Cordillera Central (Fig. 5, A7) is bounded to the north by the transcurrent sinistral Septentrional Fault Zone (SFZ). To the southeast, the Trans-Haitian thrusts's seismotectonic domain (A8) is separated by the PBFT. To the East, the zone is bounded by the Boano Fault (BoF), characterized by a strong magnetic anomaly (Monthel 2004a; GarcíaLobón and Ayala 2007), and by NNE-trending faults, visible in the current morphology and extending to the north of the Beata Ridge (Fig. 3). Based on current seismic records (Rodriguez et al. 2018), a seismicity of low magnitude but high frequency marks the northsouth limit. Another hypothesis is that this domain 
extends to the southeast, bounded to the north by the Española Fault (Fig. 5).

The main potentially active faults structuring this zone are reverse faults with a minor sinistral throw, a NW to WNW trending and SW vergence (Fig. 3). These main faults are cut by NE-SW trending sinistral strikeslip faults or NNW trending dextral strike-slip faults of smaller size. The maximum length of the NW-SE to WNW-ESE thrust fault segments is approximately 50 $\mathrm{km}$. According to the relationships of Wells and Coppersmith (1994), the maximum magnitude of the zone is close to Mw $7.0( \pm 0.3)$.

\section{The NW-SE to WNW-ESE thrust faults of the Trans-Haitian zone}

The collision between the Caribbean plate and the Hispaniola block, which began in the Paleogene, brought the south Haitian peninsula and the Cordillera Central closer. Situated between these two structural zones, the Trans-Haitian thrust belt is interpreted as a basin to the front of the collision. Today, it is a transpressive deformation zone, characterized by NW-SE to WNW-ESE trending reverse faults (Mann et al. 1995; Pubellier et al. 2000; BME 1982-1988). The latter are cut by lower dimension faults, as NNE-SSW trending sinistral strike-slip faults, or NNW-SSE trending dextral strikeslip faults. The basement of this area is probably of a Caribbean nature, covered by Neogene to Quaternary formations.

The Matheux fault (Fig. 4, Table 1, MF) corresponds to the northern boundary of the Cul-de-Sac Plain. It is the main thrust of the central Trans-Haitian mountain range (Pubellier et al. 1991). Behind the Matheux fault, the northern limit of the Trans-Haitian thrust zone (Fig. 5, Table 4, A8) corresponds to the Peralta belt front thrust (PBFT). Northwesterly trending folds and southwesterly vergent thrust faults have been localized to the front of the Matheux fault in the Gonaives Gulf, thanks to seismic profiles (Mann et al. 1995; Corbeau et al. 2016). These deformations could be related to the reverse faults described near Port-au-Prince to the north of the Enriquillo-Plantain-Garden fault zone (Terrier et al. 2014; Saint Fleur et al. 2015; Wessels et al. 2019). The western boundary of the A8 zone probably corresponds to the outermost Trans-Haitian thrusts (Corbeau et al. 2016), Fig. 3.
Pubellier et al. (1991) describe a compressional tectonic regime since 0.4 Ma which modified the TransHaitian fault system into a zone of reverse faults as it is visible in many points. In particular, these authors indicate Northeast of Port-au-Prince, near Thomazeau city, that "Eocene limestone has been transported onto Quaternary basalt". Onshore reef data indicates that tectonic uplift decreases from the northwest Peninsula of Haiti to the south-central part of western Haiti. In the central part of the domain, near the Matheux fault, the rate of uplift could be $0.19 \mathrm{~mm} /$ year (Mann et al. 1995). Moreover, macroseismic information on the earthquake of 03/9/ 1942 (Nouvelliste, 1942; earthquake catalogue in the electronic supplemental table) indicates that the epicentre would be located not far from Arcahaie. It would be the strongest earthquake observed near Matheux thrust.

The strongest earthquake associated with the A8 zone was that of November 3, 1923, of probable magnitude Mw 6.1. Based on the maximum length of the thrusts visible on shore, and using the relationships of Wells and Coppersmith (1994), the maximum magnitude of the earthquakes for the A8 zone is estimated at Mw $6.8( \pm 0.3)$.

\section{The reverse fault of Bahoruco and the Plio-Quaternary depression of Enriquillo-Neiba}

The south Hispaniola peninsula includes the Massif de la Hotte and Massif de la Selle mountains in Haiti, as well as the Sierra de Bahoruco in the Dominican Republic. It is $250 \mathrm{~km}$ long and 25 to $40 \mathrm{~km}$ wide, in an east-west direction. The late-cretaceous to Miocene carbonate recovers the basaltic basement of the Caribbean plate. This basement is outcropping in the centre of some massifs. The main deformation in the peninsula occurred from the early to mid-Pliocene, corresponding to the uplift of the massifs and the thrust towards the north of the Sierra de Bahoruco on the Enriquillo basin (García-Senz 2004). The Enriquillo Basin is a Neogene to Quaternary basin, over 4,000 m thick. Open to the sea until the mid-Holocene, the sediments in the basin from the Rio Yaque and the recent tectonic movements led to its current closing (García-Senz 2004; Díaz De Neira et al. 2007). This deformation is still active, as shown by the tilting of the paleosurfaces from the Quaternary and 
Holocene and the faults can be observed in recent deposits (Hernaiz Huerta et al. 2007).

The A6 zone (Fig. 5, Table 4) includes the Massif de la Hotte, Massif de la Selle, Massif de Bahoruco, and the sub-basin of Haiti. This is a simplifying hypothesis that brings together, on the one hand, distinct structural chains of the southern peninsula (Goreau 1981; Momplaisir 1986) and, on the other hand, part of the Caribbean plate with the NE end of the Nicaragua rise (Mauffret and Leroy 1997). In addition, based on data from aeromagnetic studies (García-Senz 2004), the Enriquillo basin is included in zone A6; however, another hypothesis is that the zone is bounded by the Bahoruco fault. In this case, the basins of Enriquillo and Azua would be included in zone A8.

The seismic activity recorded in the Bahoruco Range (Rodriguez et al. 2018) indicates reverse reactivation of west-northwest trending faults and, toward the east, dextro-normal movement of north-northeast trending faults. Moreover according to geodetic data, the region covering the Bahoruco Range to the Neiba Range shows a high displacement rate of $7 \mathrm{~mm} /$ year (Benford et al. 2012) to close to $12 \mathrm{~mm} /$ year (Calais et al. 2016; Symithe and Calais 2016). This displacement is accommodated by the reverse structures running northwest in the A6 and A8 domains. More locally, with reference to the topographic height difference along the Bahoruco fault and the age of the terraces visible on the 1/50,000 geological map (García-Senz 2004; Joubert 2004), the mean uplift attributed to the Bahoruco Fault (BF; Fig. 2) could be $0.2 \mathrm{~mm} /$ year.

Taking into account the length of the Bahoruco Fault, according to the relationships determined by Wells and Coppersmith (1994), the maximum magnitude earthquake calculated for the Bahoruco Fault is Mw 7.3 ( \pm 0.3 ). Conversely, apart from the seismicity evaluated for the Bahoruco Fault, on the basis of current seismic and tectonic data, zone A6 is characterized by a seismic background of maximal magnitude Mw 5.5.

\section{The NW-SE faults of the eastern Hispaniola peninsula}

The East-Peninsula zone (A9, Fig. 5, Table 4) comprises the Cordillera Oriental, the Caribbean coastal plain, the San Pedro basin, and part of the ancient cretaceous tecto-volcanic domains of the Cordillera Central. To the East, the limit of zone A9 corresponds to the Mona rift (A11) and its southern extension. To the west, the limit is situated directly above the Bonao Fault (BoF), extended by submeridian faults (Fig. 3). The northern boundary is the Septentrional Fault Zone, while the A2 zone is to the south (Fig. 5).

The Bonao fault limits two major structural blocks, characterized by different Turonian-Campanian volcanic stratigraphies, geochemical composition and physical characteristics of their constituent igneous rocks (Mann et al. 1991; Escuder Viruete et al. 2008). In the current tectonic context, Hernaiz (2004) describes the Bonao Fault as the western boundary of the Bonao Quaternary Basin, marked by the apex of powerful current or sub-current alluvial fans, in connection with a normal or normal dextral movement of the fault.

The Cordillera Oriental (Fig. 2) corresponds to an anticlinal formed during the Late Cretaceous with a WNW-ESE axis, close to the south, interrupted by the Septentrional fault zone in the North. The eastern peninsula of Hispaniola acquired its current topography during the Quaternary (Díaz De Neira et al. 2007). The faults structuring the range have a WNW-ESE to NWSE direction and a vertical plane.

The neotectonic activity in the Cordillera Oriental is evident in the elevation of the Plio-Quaternary reef platform (Los Haitises), which currently presents itself as a structural relief elevated to over 300 to $350 \mathrm{~m}$; according to these data, the average rate of elevation in this region would be about $0.193 \mathrm{~mm} /$ year. (Diaz de Neira 2004a; Díaz De Neira et al. 2007). This deformation is accommodating by the vertical component of the movement of faults, among them, the main faults are the Vacama and Yabon faults (YFS and VF; Fig. 3). These faults produce a clear anomaly on the magnetic map (Monthel 2004b; García-Lobón and Ayala 2007).

The Vacama Fault (VF) is the eastern border of the Eastern Cordillera. It limits the early Pliocene reef platform (Los Haitises formation) from the middle-terminal Pleistocene limestone terraces (La Isabela formation) by an escarpment about $20 \mathrm{~m}$ high (Monthel 2004b). According to García-Senz and Pérez-Estaún (2012), this fault was linked to the evolution of the Mona Rift. Based on the $20 \mathrm{~m}$ elevation of the late Pleistocene terrace; Diaz de Neira et al. (2015) indicates an uplift rate of 0.033-0.068 mm/year.

The Yabon Fault forms a straight escarpment, with triangular facets, sudden changes in slope, anomalies in the drainage network (Díaz De Neira et al. 2007). The installation of the Seibo River and its tributary the 
Magua stream along its trace are one more argument about its tectonic activity (Diaz de Neira 2004a). Along the Yabon Fault System (YFS), the calcareous formation of the Early Pleistocene (dated more or less 780 kyr) could be shifted by more than $100 \mathrm{~m}$ (Monthel 2004a). This morphologic shift may indicate a mean vertical displacement of the Yabon faults between the Quaternary and Today by close $0.15 \mathrm{~mm} /$ year.

Further to the west, the height differences recorded along the faults decrease significantly. The Española Fault Zone (EFZ; Fig. 3) is hidden by the thick PlioQuaternary cover of the Caribbean coastal plain (Llanura Costera del Caribe). The EFZ corresponds to a major crustal structure that consists of two parallel segments, bounding the tecto-volcanic Bonao domain characterized by basic to ultrabasic rocks (Pérez-Estaún et al. 2007; Escuder Viruete et al. 2008). This system is associated with a very strong magnetic and gravimetric anomaly (García-Lobón and Ayala 2007). To the northeast of the EFZ, the cretaceous basement belongs to the Cordillera Oriental. To the southeast, cretaceous formations have the same paleo-structural affinity as those of the Cordillera Central. Vertically above the EFZ, the American plate subducts significantly under the Hispaniola block and Caribbean plate (Fig. 2). The EFZ had a thrusting action during the compression phase of the Late Cretaceous to Palaeocene, then a sinistral shearing motion in the Neogene (Hernaiz 2004). To the east of Santo Domingo, the terraces of the Late Pleistocene of the Llanura del Caribe, dated $121( \pm 9) \mathrm{kyr}$, are close to $10 \mathrm{~m}$ above the normal level, indicating a mean uplift of $0.06 \mathrm{~mm} /$ year (Diaz de Neira 2004b).

The San Pedro Fault (SPF) extends the Española Fault Zone. It underlines a $200 \mathrm{~m}$ high cliff marking the limit between the insular plateau, to the north, and the Neogene San Pedro Basin, to the south (Granja Bruña et al. 2014), Fig. 6. The San Pedro basin is an E-W trending bathymetric depression classically interpreted as a "fore-arc type basin". This basin has a smooth seafloor morphology and an average water depth of $1400 \mathrm{~m}$. The San Pedro Basin corresponds to the offshore part of the A9 zone.

The transtensive deformation of the A9 zone appears larger in the east than in the west. The current transtensive context of the Cordillera Oriental can be explained by "slab roll back" in the upper lithosphere following the model of Heuret and Lallemand (2005). According to this hypothesis, the American lithosphere showed a gradual retreat of the subducted plate, and at the same time a gradual dip of this plate, while the upper plate remained fixed, inducing a distensive back-arc deformation in the surface.

The Española fault zone and San Pedro fault are presumed as two systems potentially active, but with deformation rates lower than those of the Yabon and Vacama faults (Fig. 4, Table 1). To the west of zone A9, as indicated above, the Cordillera Central is currently experiencing a transpressive deformation (Fig. 2). An intermediary zone is located between the Cordilleras Central and Oriental. This may be subdivided (green dotted line on Fig. 5), or integrated into zone A9, in order to facilitate future probabilistic seismic hazard calculations. Apart from the maximal seismicity evaluated for the potentially active faults described above (VF, YF, EFZ, SPF; (Fig. 4, Table 1), the A3 seismic zone is associated with a seismic background estimated at a maximum magnitude $\mathrm{Mw}$ 5.5.

\section{Conclusions}

A seismotectonic map and the characterization of active or potentially active faults were established based on a large number of data of varied nature and quality. For example, the structural analysis was facilitated in the Dominican Republic by $1 / 50,000$ scale geologic maps published between 1997 and 2010, whereas in Haiti we only had a geologic map at the 1/250,000 scale, published in 1989. To establish a seismic catalogue, few usable data before the 1960s were available. The location, focal depth and magnitude of earthquakes prior to this date are highly uncertain. Few paleo-seismic data were available to evaluate the motion rate of active faults. Apart from the septentrional fault system (SFZ), these rates are estimated from altimetry measurements (geodetic or topographic). Despite the high uncertainty of these rates, they allow an initial assessment of return periods of the strong earthquakes characterizing the active fault systems.

From the seismotectonic map and knowledge of the geological and geophysical context, a model of the seismic sources was proposed, distinguishing among the large systems of active faults, the near seismic domains $(<35$ $\mathrm{km}$ depth) with diffuse seismicity, and the deep seismic zones with the subduction of the American plate under the Caribbean plate. Locally, several hypotheses are proposed. In a later phase, the results were directly integrated into probabilistic seismic hazard calculations for the metropolitan area of Santo Domingo (Bertil et al. 2015), for which the implemented seismic zonation was an essential input. 
Despite the limitations outlined above, the map and the characterization of active faults constitute the first database of synthetic information on the active or potentially active faults of Hispaniola. Apart from the setup of a better network of seismic measurements (and monitoring), improvement in these results would require more precise and more numerous neotectonics and paleoseismic analyses.

The characterization of potentially active faults is especially important in high-stakes regions such as capital cities (Port-au-Prince and Santo Domingo) and urban zones exposed to high seismic hazard. Many cities in Hispaniola are heavily exposed to seismic risk because of their proximity to seismic sources, high vulnerability of existing infrastructure and large concentration of population as well as poor quality of soils. Improved knowledge of seismotectonic sources could also lead to better recommendations for seismic construction in each of the two countries.

Supplementary Information The online version contains supplementary material available at https://doi.org/10.1007/s10950021-09985-0.

Acknowledgements This study was part of the United Nations Development Program "Estudio de la Amenaza Sísmica y Vulnerabilidad Física del Gran Santo Domingo (2013-2016)”.

Funding This work was funded by the European Development Fund in the Dominican Republic and by joint co-financing from the internal BRGM project DEV HISPALEA 2014-2015.

Open Access This article is licensed under a Creative Commons Attribution 4.0 International License, which permits use, sharing, adaptation, distribution and reproduction in any medium or format, as long as you give appropriate credit to the original author(s) and the source, provide a link to the Creative Commons licence, and indicate if changes were made. The images or other third party material in this article are included in the article's Creative Commons licence, unless indicated otherwise in a credit line to the material. If material is not included in the article's Creative Commons licence and your intended use is not permitted by statutory regulation or exceeds the permitted use, you will need to obtain permission directly from the copyright holder. To view a copy of this licence, visit http://creativecommons.org/licenses/by/4.0/.

\section{References}

Ali ST, Freed AM, Calais E, Manaker DM, McCann WR (2008) Coulomb stress evolution in Northeastern Caribbean over the past 250 years due to coseismic, postseismic and interseismic deformation. Geophys J Int 174:904-6918
Alvarez L, Chuy T, Garcia J, Moreno B, Alvarez H, Blanco M, Exposito O, Gonzalez O, Fernandez AI (1999) An earthquake catalogue of Cuba and neighboring areas. The Abdus Salam International Centre for Theoretical Physics. Internal Report IC/IE/99/1, 62p. Trieste, Italy

B.M.E (1982-1988) - Carte géologique à 1/250 000 de la République d'Haïti (en 4 feuilles) - Editeur C.E.R.C.G. IMAGEO, CNRS, Paris: 1- Bien Aimé Monplaisir R, Boisson D (1987): feuille Sud-Est (feuille de Port-auPrince)- 2- Boisson D, Pubellier M (1987): feuille Nord-Est (feuille de Cap-Haitien) - 3- Pubellier M, Boisson D (1988): feuille Nord-Ouest (feuille de Môle St Nicolas) - 4- Amilcar H, Bien Aimé Monplaisir R (1988) : feuille du Sud-Ouest (feuille des Cayes).

Bakun WH, Flores CH, Uri S (2012) Significant earthquakes on the Enriquillo fault system, Hispaniola, 1500-2010: Implications for seismic hazard. Bull Seismol Soc Am 102:18-30

Benford B, DeMets C, Calais E (2012) GPS estimates of microplate motions, northern Caribbean: evidence for a Hispaniola microplate and implications for earthquake hazard. Geophys J Int 191(2):481-490

Bertil D, Prépetit C, Belvaux M, Noury G et al (2013) Microzonage sismique de Port-au-Prince (Haiti) : rapport de synthèse. Rapport final BRGM/RC-63100-FR, 69 p, 31 fig, 8 tab, 6 pl. h.t. https://www.mtptc.gouv. $\mathrm{ht} /$ media/upload/doc/publications/MicroSynthese.pdf

Bertil D, Terrier M, Belvaux M (2015) Análisis de las fuentes sísmicas y evaluación de la amenaza sísmica regional del gran Santo Domingo. "Estudio de la amenaza sísmica y vulnerabilidad física del Gran Santo Domingo" - Actividad 1.1. BRGM/RP-65305-FR, $149 \mathrm{p}$

Biju-Duval B, Bizon G, Mascle A, Muller C (1982) Active margin processes; field observations in southern Hispaniola. Am Assoc Petr Geol Mem 34:325-344

Byrne DB, Suarez G, McCann WR (1985) Muerto Trough subduction - microplate tectonics in the northern Caribbean? Nature 317:420-421. https://doi.org/10.1038/317420a0

Calais E, Mercier de Lepinay B (1991) From transtension to transpression along the northern Caribbean plate boundary off Cuba: implications for the Recent motion of the Caribbean plate. Tectonophysics 186:329-350

Calais E, Mazabraud Y, Mercier de Lépinay B, Mann P, Mattioli G, Jansma P (2002) Strain partitioning and fault slip rates in the northeastern Caribbean from GPS measurements. Geophys Res Lett 29(18):3-1

Calais E, Freed A, Mattioli G, Amelung F, Jónsson S, Jansma P, Momplaisir R (2010) Transpressional rupture of an unmapped fault during the 2010 Haiti earthquake. Nat Geosci 3(11):794-799

Calais E, Symithe S, Mercier de Lépinay B, Prépetit C (2016) Plate boundary segmentation in the northeastern Caribbean from geodetic measurements and Neogene geological observations. C R Geosci 348:42-51. https://doi.org/10.1016/j. crte.2015.10.007

Case J, MacDonald WD, Fox PJ (1990) Caribbean crustal provinces; seismic and gravity evidence. in: Dengo, G, and Case, J. E (Eds). The Geology of North America, The Caribbean Region (A decade of North American Geology)», The Geological Society of America, Boulder, CO, vol. H, p. $15-36$ 
Chuy RT, Alvarez J (1988) Sismicidad histórica de la Española, Comunicaciones Cientificas sobre Geofísica y Astronomía, 12 pp.no. 16, La Habana, 1988

Corbeau J (2015) Dynamique d'une frontière transformante dans un contexte de collision oblique : étude de la limite nord de la plaque Caraïbe dans la région d'Haïti. Géophysique, [physics.geo-ph]. Université Pierre et Marie Curie - Paris VI. Français. <NNT : 2015PA066621>. <tel-01413773>

Corbeau J, Rolandone F, Leroy S, Mercier de Lépinay B, Meyer B, Ellouz-Zimmermann N, Momplaisir R (2016) The Northern Caribbean plate boundary in the Jamaica Passage: structure and seismic stratigraphy. Tectonophysics 675:209226. https://doi.org/10.1016/j.tecto.2016.03.022

Corbeau J, Gonzalez OL, Clouard V, Rolandone F, Leroy S, Keir D, Prepetit C (2019) Is the local seismicity in western Hispaniola (Haiti) capable of imaging northern Caribbean subduction? Geosphere. 15:1738-1750. https://doi. org/10.1130/GES02083.1

DeMets C, Wiggins-Grandison M (2007) Deformation of Jamaica and motion of the Gonave microplate from GPS and seismic data. Geophys J Int 168(1):362-378

DeMets C, Gordon RG, Argus DF (2010) Geologically current plate motions. Geophys J Int 181:1-80. https://doi. org/10.1111/j.1365-246X.2009.04491.x

Diaz de Neira A (2004a) Mapa Geológico de la hoja a E. 1:50.000 $\mathrm{n}^{\circ}$ 6372-I (Miches) y Memoria correspondiente. Proyecto LZona SO de Cartografía Geotemática de la República Dominicana. Programa SYSMIN. Dirección General de Minería, Santo Domingo

Diaz de Neira A (2004b) Mapa Geológico de la hoja a E. 1:50.000 $n^{\circ}$ 6271-II (Boca Chica) y Memoria correspondiente. Proyecto L-Zona SO de Cartografía Geotemática de la República Dominicana. Programa SYSMIN. Dirección General de Minería, Santo Domingo

Díaz De Neira JA, Martín-Serrano A, Escuer J (2007) Evolución geomorfológica de la Cordillera Oriental Dominicana. Bol Geol Min 118(2):385-400 ISSN: 0366-0176

Diaz de Neira JA, Braga JC, Mediato J, Lasseur E, Monthel J, Hernaiz PP, Pérez-cerdan F, Lopera E, Thomas A (2015) Plio-Pleistocene paleogeography of the Llanura Costera del Caribe in Eastern Hispaniola (Dominican Republic): interplay of geomorphic evolution and sedimentation. Sediment Geol 325:90-105

Dillon WP, Austin JA, Scanlon KM, Edgar NT, Parson LM (1992) Accretionary margin of northwestern Hispaniola: morphology, structure and development of part of the northern Caribbean plate boundary. Mar Petrol Geol 9(1):70-88 0264-8172/92/010070-19

Dolan FD, Bowman DD (2004) Tectonic and seismologic Setting of the 22 September 2003, Puerto Plata, Dominican Republic earthquake: implications for earthquake hazard in Northern Hispaniola. Seismol Res Lett 75(5):587-597

Dolan JE, Mullins HT, Wald DJ (1998) Active tectonics of the north-central Caribbean: Oblique collision, strain partitioning, and opposing subducted slabs, in Dolan, J. E, and Mann, P, eds, Active Strike-Slip and Collisional Tectonics of the Northern Caribbean Plate Boundary Zone: Boulder, Colorado, Geological Society of America Special Paper 326

Douilly R, Haase JS, Ellsworth WL, Bouin MP, Calais E, Symithe SJ, Armbruster JG, Mercier de Lépinay B, Deschamps A,
Mildor S-L et al (2013) Crustal structure and fault geometry of the 2010 Haiti earthquake from temporary seismometer deployments. Bull Seismol Soc Am 103(4):2305-2325

Douilly R, Aochi H, Calais E, Freed AM (2015) 3D dynamic rupture simulations across interacting faults: The $\mathrm{Mw}$ 7. 0 , 2010, Haiti earthquake. J Geophys Res 120(2):1108-1128

Edgar NT, Ewing JI, Hennion J (1971) Seismic refraction and reflection in Caribbean Sea. AAPG Bull 55(6):833-870

Escuder Viruete J, Contreras F, Joubert M, Urien P, Stein G, Weis D, Pérez-Estaun A (2007) Tectónica y geoquímica de la Formación Amina: registro del arco isla Caribeño primitivo en la Cordillera Central, República Dominicana. Bol Geol Min 118(2):221-242 ISSN: 0366-0176

Escuder Viruete J, Joubert M, Urien P, Friedman R, Weis D, Ullrich T, Pérez-Estaún A (2008) Caribbean island-arc rifting and back-arc basin development in the Late Cretaceous: Geochemical, isotopic and geochronological evidence from Central Hispaniola. Lithos 104:378-404

Ewing J, Antoine J, Ewing M (1960) Geophysical measurements in the western Caribbean Sea and in the Gulf of Mexico. J Geophys Res 65(12):4087-4126

Flores CH, ten Brink US, Bakun WH (2011) Accounts of damage from historical earthquakes in the northeastern Caribbean, to aid in the determination of their location and intensity magnitudes. Open-File Report 2011-1133, US Department of the Interior. US Geological Survey

García-Lobón JL, Ayala C (2007) Cartografía geofísica de la República Dominicana: datos de densidad, susceptibilidad magnética y magnetización remanente. Bol Geol Min 118(2):175-194 ISSN: 0366-0176

García-Senz J (2004) Mapa Geológico de la hoja a E. 1:50.000 n 5871-III (Jimaní) y Memoria correspondiente. Proyecto LZona SO de Cartografía Geotemática de la República Dominicana. Programa SYSMIN. Dirección General de Minería, Santo Domingo.

García-Senz J, Pérez-Estaún A (2012) Modes of active deformation in Eastern Hispaniola. EGU Gen Assembly Geophys Res Abstracts 14:14221

Gomez J (2004) Mapa Geológico de la hoja a E. 1:50.000 n 6071IV (Yayas de Viajama) y Memoria correspondiente. Proyecto L-Zona SO de Cartografía Geotemática de la República Dominicana. Programa SYSMIN. Dirección General de Minería, Santo Domingo

Goreau P (1981) "The Tectonic Evolution of the North Central Caribbean Plate Margin," PhD Thesis, Massachusetts Institute of Technology, Department of Earth, Atmospheric and Planetary Science. Cambridge, MA: 245

Granja Bruña JL, ten Brink US, Carbó-Gorosabel A, MuñozMartín A, Gómez Ballesteros M (2009) Morphotectonics of the central Muertos thrust belt and Muertos Trough (northeastern Caribbean). Mar Geol (ISSN: 0025-3227) 263, 7-33. https://doi.org/10.1016/j.margeo.2009.03.010

Granja Bruña JL, Muñoz-Martín A, ten Brink US, CarbóGorosabel A, Llanes Estrada P, Córdoba-Barba D, MartínDávila J, Catalán Morollón M (2010) Gravity modeling of the Muertos Trough and tectonic implications (NE Caribbean). Mar. Geophys. Res (ISSN: 0025-3235) 31 (4), 263-283. https://doi.org/10.1007/s11001-010-9107-8

Granja Bruña JL, Carbó-Gorosabel A, Llanes Estrada P, MuñozMartín A, ten Brink US, Gómez Ballesteros M, Druet M, Pazos A (2014) Morphostructure at the junction between the 
Beata ridge and the Greater Antilles island arc (offshore Hispaniola southern slope). Tectonophysics 618:138-163. https://doi.org/10.1016/j.tecto.2014.02.001

Grases J (1990) Terremotos destructores del Caribe: 1502 - 1990. Una contribuciàn al Decenio Internacional para la Reduciàn de los Desastres Naturales, Caracas, Agosto de 1990. UNESCO - RELACIS

Gutenberg B, Richter C (1954) Seismicity of the earth and associated phenomena. Princeton University Press, Princeton

Hayes G, Briggs R, Sladen A, Fielding E, Prentice C, Hudnut K, Mann P, Taylor F, Crone A, Gold R et al (2010) Complex rupture during the 12 January 2010 Haiti earthquake. Nat Geosci 3(11):800-805

Hernaiz PP (2004) Mapa Geológico de la hoja a E. 1:50.000 n ${ }^{\circ}$ 6172-III (Arroyo Caña) y Memoria correspondiente. Proyecto L-Zona SO de Cartografía Geotemática de la República Dominicana. Programa SYSMIN. Dirección General de Minería, Santo Domingo

Hernaiz Huerta PP, Pérez-Estaún A (2002) Estructura del cinturón de pliegues y cabalgamientos de Peralta, República Dominicana. Acta Geol Hisp 37:183-205

Hernaiz Huerta PP, Díaz de Neira JA, García-Senz J, Deschamps I, Genna A, Nicole N, Lopera E, Escuder Viruete J, Ardévol Oró LL, Pérez-Estaún A (2007) La estructura del suroeste de la República Dominicana: un ejemplo de deformación en régimen transpresivo. Bol Geol Min 118(2):337-358 ISSN: 0366-0176

Heuret A, Lallemand S (2005) Plate motions, slab dynamics and back-arc deformation. Phys Earth Planet Inter 149:31-51

Iniguez H (1985) Documentos de terremotos historicos (15511959) en Republica Dominicana (http://www.desastre. org/home/data/pdf/risk/esp/Terremotos $\% 20$ Historicos $\% 20$ por\%20Ing.\%20Iniguez.1985.pdf)

ISC (2014) International Seismological Centre, On-line Bulletin, http://www.isc.ac.uk, Internat. Seis. Cent, Thatcham, United Kingdom

ISC GEM, Storchak DA, Di Giacomo D, Bondar I, Engdahl ER, Harris J, Lee WHK, Villaseñor A, Bormann P (2013) Public Release of the ISC-GEM Global Instrumental Earthquake Catalogue (1900-2009). Seismol Res Lett 84(5):810-815. https://doi.org/10.1785/0220130034

Joubert M (2004) Mapa Geológico de la hoja a E. 1:50.000 n 5870-I and IV (Puerto Escondido) y Memoria correspondiente. Proyecto L-Zona SO de Cartografía Geotemática de la República Dominicana. Programa SYSMIN. Dirección General de Minería, Santo Domingo

Leroy S, Ellouz-Zimmermann N, Corbeau J, Rolandone F, Mercier de Lépinay B et al (2015) Segmentation and kinematics of the North America-Caribbean plate boundary offshore Hispaniola. Terra Nova 27:467-478. https://doi. org/10.1111/ter.12181

Lewis IF, Escuder Viruete I, Hernaiz Huerta P.P, Gutierrez G, Draper G. and Pérez-Estaún A (2002) Subdivisión geoquímica del Arco Isla Circum-Caribeño, Cordillera Central Dominicana: implicaciones para la formación, acrecion y crecimiento cortical en un ambiente intraoceánico, Acta Geol Hisp, v. 37, n 2-3, p. 81-122

Manaker DM, Calais E, Freed AM, Ali ST, Przybylski P, Mattioli G, Jansma P, Prépetit C, De Chabalier JB (2008) Interseismic plate coupling and strain partitioning in the Northeastern
Caribbean. Geophys J Int 174:889-903. https://doi. org/10.1111/j.1365-246X.2008.03819.x

Mann P, Burke K (1984) Matumoto T (1984) Neotectonics of Hispaniola: plate motion, sedimentation, and seismicity at a restraining bend. Earth Planet Sci Lett 70:311-324

Mann P, Draper G, Lewis JF (1991) An overview of the geologic and tectonic development of Hispaniola. In:P. Mann, G. Draper and J.F. Lewis (Editors), Geologic and Tectonic Development of the North America-Caribbean Plate Boundary in Hispaniola. Geol. Soc. Am, Spec.Pap, 262: 1-28

Mann P, Taylor F, Edwards RL, Ku TL (1995) Actively evolving microplate formation by oblique collision and sideways motion along strike-slip faults: an example from the northeastern Caribbean plate margin. Tectonophysics 246(1):1-69

Mann P, Calais E, Ruegg JC, DeMets C, Jansma PE, Mattioli GS (2002) Oblique collision in the northeastern Caribbean from GPS measurements and geological observations. Tectonics 21:7-1-7-26. https://doi.org/10.1029/2001TC001304

Mauffret A, Leroy S (1997) Seismic stratigraphy and structure of the Caribbean igneous province. Tectonophysics 283:61104. https://doi.org/10.1016/S0040-1951(97)00103-0

Maus U, Barckhausen U, Berkenbosch H, Bournas N, Brozena J, Childers V, Dostaler F, Fairhead JD, Finn C, von Frese RRB, Gaina C, Golynsky S, Kucks R, Lühr H, Milligan P, Mogren S, Muller RD, Olesen O, Pilkington M, Saltus R, Schreckenberger B, Thebault E, Tontini V (2008) EMAG2: A 2-arc min resolution Earth Magnetic Anomaly Grid compiled from satellite, airborne, and marine magnetic measurements. Geochem Geophys Geosyst 10:Q08005. https://doi. org/10.1029/2009GC002471

McCann W, Feldman L, McCann M (2011) Catalog of felt earthquakes for Puerto Rico and neighboring islands 1493-1899 with additional information for some 20th century earthquakes. Revista Geofísica 62:141-293

Mercier de Lépinay B, Mauffret A, Jany I, Bouysse P, Mascle A, Renard V, Stephan JF, Hernandez E (1988) Une collision oblique sur la bordure nord-caraïbe à la jonction entre la ride de Beata et la fosse de Muertos. C R Acad Sci Paris 307(Serie II): 1289-1296

Mercier de Lepinay B, Deschamps A, Klingelhoefer F, Mazabraud Y, Delouis B, Clouard V, Hello Y, Crozon J, Marcaillou B, Graindorge D, Vallee M, Perrot J, Bouin M.P, Saurel J.M, Charvis P, St-Louis M (2011) The 2010 Haiti earthquake: A complex fault pattern constrained by seismologic and tectonic observations, Geophysical Research Letters (0094-8276) (Amer Geophysical Union), 11, Vol. 38 , N. L22305, P. 7 p, 2011. https://doi.org/10.1029/2011GL049799

Molnar P, Sykes LR (1969) Tectonics of the Caribbean and middle America regions from focal mechanisms and seismicity. Geol Soc Am Bull 80:1639-1684

Momplaisir R (1986) Contribution à l'étude géologique de la partie orientale du massif de la Hotte (Presqu'île du Sud d'Haïti): synthèse structurale des marges de la Presqu'île (Ph. D. thesis, Paris)

Monthel J (2004a) Mapa Geológico de la hoja a E. 1:50.000 n 6372-II (El Seibo) y Memoria correspondiente. Proyecto LZona SO de Cartografía Geotemática de la República Dominicana. Programa SYSMIN. Dirección General de Minería, Santo Domingo

Monthel J (2004b) Mapa Geológico de la hoja a E. 1:50.000 ${ }^{\circ}$ 6472-II (El Salado) y Memoria correspondiente. Proyecto L- 
Zona SO de Cartografía Geotemática de la República Dominicana. Programa SYSMIN. Dirección General de Minería, Santo Domingo

Pérez-Estaún A, Hernaiz Huerta PP, Lopera E, Joubert M et al (2007) Geología de la República Dominicana: de la construcción de arco-isla a la colisión arco-continente. Bol Geol Min 118(2):157-174 ISSN: 0366-0176

Pindell JL, Kennan L (2009) Tectonic evolution of the Gulf of Mexico, Caribbean and Northern South America in the mantle reference frame: an update. In: James K, AntonietaLorente M, Pindell J (eds) The geology and evolution of the region between North and South America. Geological Society of London, London, pp 227-242

Prentice CS, Mann P, Peña LR, Burr G (2003) Slip rate and earthquake recurrence along the central Septentrional fault, North American-Caribbean plate boundary, Dominican Republic. J Geophys Res 108(B3):2149. https://doi. org/10.1029/2001JB000442

Prentice CS, Mann P, Crone AJ, Gold RD, Hudnut KW, Briggs RW, Koehler RD, Jean P (2010) Seismic hazard of the Enriquillo-Plantain Garden fault in Haiti inferred from Palaeoseismology. Nat Geosci 3:789-793

Pubellier M, Vila JM, Boisson D (1991) North Caribbean neotectonic events: the Trans-Haitian fault system. Tertiary record of an oblique transcurrent shear zone uplifted in Hispaniola. Tectonophysics 194:217-236

Pubellier M, Mauffret A, Leroy S, Vila JM, Amilcar H (2000) Plate boundary readjustment in oblique convergence: Example of the Neogene of Hispaniola, Greater Antilles. Tectonics 19(4):630-648

Rathje EM, Bachhuber J, Bulberg R, Cox BR, Kottke A, Wood C, Green RA, Olson S, Wells D, Rix G (2011) Damage patterns in port-au-prince during the 2010 Haiti earthquake. Earthquake Spectra 27(1):117-136. https://doi.org/10.1193 $/ 1.3637056$

Rodriguez J, Havskov J, Botter Sorebseb M, Santos LF (2018) Seismotectonics of south-west Dominican Republic using recent data. J Seismol 22:883-896. https://doi.org/10.1007 /s10950-018-9738-9

Rodríguez-Zurrunero A, Granja-Bruña JL, Muñoz-Martín A, Leroy S, ten Brink U, Gorosabel-Araus JM, Gómez de la Peña L, Druet M, Carbó-Gorosabel A (2020) Along-strike segmentation in the northern Caribbean plate boundary zone (Hispaniola sector): tectonic implications. Tectonophysics, Elsevier 2020:228322. https://doi.org/10.1016/j.tecto.2020.228322

Russo RM, Villaseñor A (1995) The 1946 Hispaniola earthquake and the tectonics of the North America Caribbean plate boundary, northeastern Hispaniola. J Geophys Res 100:6265-6280

Saint Fleur N, Feuillet N, Grandin R, Jacques E, Weil-Accardo J, Klinger Y (2015) Seismotectonics of southern Haiti: a new faulting model for the 12 January 2010 M7.0 earthquake. Geophys Res Lett 42:10,273-10,281. https://doi.org/10.1002 /2015GL065505

Scherer J, Baltenweck R (1913) Catalogue chronologique des tremblements de terre ressentis dans l'île d'Haïti de 1551 à 1900: Bulletin Semestriel de l'Observatoire Météorologique du Séminaire-Collège St.-Martial, Port-au-Prince, Haïti, Juillet-Décembre 1913: Port-au-Prince, Haiti, Imprimerie National, p.147-151
SISFRANCE Antilles - Sismicité historique de la France AntillesGuyane-Mer des Caraïbes, BRGM (2009), Available online: https://sisfrance.irsn.fr/Antilles/

Stanek KP, Maresch WV, Pindell JL (2009) The geotectonic story of the Northwestern branch of the Caribbean Arc : implications from structural and geochronological data of Cuba. Geol Soc Lond Spec Publ 328:361-398. https://doi.org/10.1144/SP328.15

Sykes LR, Ewing WM (1965) The Seismicity of the Caribbean Region. J Geophys Res 70

Symithe S, Calais E (2016) Present-day shortening in Southern Haiti from GPS measurements and implictions for seismic hazard. Tectonophysics 679:117-124. https://doi. org/10.1016/j.tecto.2016.04.034

Symithe SJ, Calais E, Haase JS, Freed AM, Douilly R (2013) Coseismic slip distribution of the 2010 M 7.0 Haiti earthquake and resulting stress changes on regional faults. Bull Seismol Soc Am 103(4):2326-2343

Symithe S, Calais E, de Chabalier JB, Robertson R, Higgins M (2015) Current block motions and strain accumulation on active faults in the Caribbean. J Geophys Res Solid Earth 120:3748-3774. https://doi.org/10.1002/2014JB011779

SYSMIN Project (1999-2010) Mapa geologica de la República Dominicana, escala 1: 50.000 - UE, Programa de Desarrollo Geológico Minero (SYSMIN), Realizado por el Consorcio IGME-BRGM-INYPSA, Director del Proyecto: Eusebio Lopera Caballero (IGME), Supervisión Técnica: UTGSYSMIN (TYPSA). Maps and explanatory notes, in the text, number of the sheet in reference

Tanner JG, Shepherd JB (1997) Seismic hazard in Latin America and the Caribbean, Final Report. Volume I: Project Catalogue and Seismic Hazard Maps. Instituto Panamericano de Geografia y Historia (IPGH). Project n89-0190. International Development Research Centre, Ottawa, Canada, $143 \mathrm{p}$

ten Brink US, Bakun WH, Flores CH (2011) Historical perspective on seismic hazard to Hispaniola and the northeast Caribbean region. J Geophys Res 116:B12318. https://doi. org/10.1029/2011JB008497

Terrier M, Bialkowski A, Nachbaur A, Prépetit C, Joseph YF (2014) Revision of the geological context of the Port-auPrince metropolitan area, Haiti: implications for slope failures and seismic hazard assessment. Nat Hazards Earth Syst Sci 14:2577-2587 www.nat-hazards-earth-syst-sci.net/14/2577 /2014/doi:10.5194/nhess-14-2577-2014

Wells DL, Coppersmith KJ (1994) New empirical relationships among magnitude, rupture length, rupture width, rupture area, and surface displacement. Bull Seismol Soc Am 84:974-1002

Wessels RJF, Ellouz-Zimmermann N, Bellahsen N, Hamon Y, Rosenberg C, Deschamps R, Momplaisir R, Boisson D, Leroy S (2019) Polyphase tectonic history of the Southern Peninsula, Haiti: from folding and thrusting to transpressive strike-slip. Tectonophysics 751:125-149. https://doi. org/10.1016/j.tecto.2018.12.011

Publisher's note Springer Nature remains neutral with regard to jurisdictional claims in published maps and institutional affiliations. 